WISSENSCHAFTSZENTRUM BERLIN FÜR SOZIALFORSCHUNG

SOCIAL SCIENCE RESEARCH CENTER BERLIN

Philipp Rehm

\title{
Citizen Support for the Welfare State: \\ Determinants of Preferences for Income \\ Redistribution
}

SP II $2005-02$

January 2005

ISSN Nr. $0722-6748$

Research Area

Markets and Political Economy

Working Group

Institutions, States, Markets
Forschungsschwerpunkt Markt und politische Ökonomie

Arbeitsgruppe

Institutionen, Staaten, Märkte 
Zitierweise/Citation:

Philipp Rehm, Citizen Support for the Welfare State:

Determinants of Preferences for Income Redistribution,

Discussion Paper SP II 2005 - 02 Wissenschaftszentrum

Berlin, 2005.

Wissenschaftszentrum Berlin für Sozialforschung $\mathrm{gGmbH}$,

Reichpietschufer 50, 10785 Berlin, Germany, Tel. (030) 25491 - 0

Internet: www.wz-berlin.de 


\section{Citizen Support for the Welfare State:}

Determinants of Preferences for Income Redistribution

by Philipp Rehm

This paper explores the determinants of individual level support for income redistribution by the government. It argues that there are two sources of preference formation when it comes to redistribution. People are either in favor of income redistribution because they are disadvantaged, or they favor redistribution as a means to insure against income shocks. The paper explores both logics, but focuses on the latter. Four risk factors are hypothesizes to influence an individual's preferences over income redistribution: a) structural change; b) exposure to international competition; c) specificity of skills; and d) occupational unemployment. Some of these measures are novel. The paper relies on the European Social Survey 2002/2003 in order to test the formulated hypotheses. The results show that a) skill specificity and occupational unemployment are important determinants of individual preferences over redistribution whereas b) structural change and exposure to international competition are not.

Keywords: Public Opinion, Preferences, Redistribution, Varieties of Capitalism, Trade, Unemployment, Occupations

JEL Classification: D31, D72, E24, H53 


\section{Öffentliche Meinung und der Wohlfahrtsstaat: Bestimmungsgründe von Unterstützung für Einkommen-Umverteilung}

Diese Arbeit untersucht die Ursachen von Unterstützung für staatliche EinkommensUmverteilung, auf der individuellen Ebene. Es wird argumentiert dass es zwei Quellen für Präferenzen für Umverteilung gibt. Man ist entweder für EinkommensUmverteilung weil man benachteiligt ist. Oder man ist dafür, weil Umverteilung als Versicherung gegen bestimmte Einkommens-Fluktuationen dient. Die Arbeit untersucht beide Quellen, konzentriert sich aber auf die Logik von Umverteilung als RisikoAbsicherung. Es werden vier Risiko-Faktoren vorgeschlagen, die einen Einfluss auf individuelle Präferenzen für Einkommens-Umverteilung einen Einfluss haben könnten: a) struktureller Wandel; b) internationale Konkurrenz; c) spezialisiertes Humankapital und d) Arbeitslosigkeit innerhalb von Berufsgruppen. Einige dieser Faktoren werden in neuartiger Weise operationalisiert. Um die formulierten Hypothesen zu testen, benutzt die Arbeit das ,European Social Survey 2002/2003’. Die Resultate ergeben dass a) spezialisiertes Humankapital und Arbeitslosigkeit innerhalb von Berufsgruppen wichtige Ursachen für Präferenzen für Umverteilung sind. Hingegen können b) struktureller Wandel und internationale Konkurrenz nicht als wichtige Faktoren für Präferenzen hinsichtlich von Einkommens-Umverteilung etabliert werden. 


\section{Introduction}

The main question of this paper is: What determines individual level support for income redistribution by the government? ${ }^{1}$ This question is important for at least two reasons. To begin, redistribution is a central activity of all governments in Western democracies. All OECD countries redistribute substantial parts of their gross national products. Second, redistributional questions are one of the most contested issues in democracies. People align with and vote for parties because of their different degrees of support for income redistribution. Party competition in most democracies is heavily influenced by competing positions on redistributional issues. Indeed, redistributional preferences are the single best predictor of partisan preferences (Kitschelt \& Rehm 2004a). In addition, from a normative perspective it seems desirable to have programmatic linkages between the electorate and parties. Politicians, according to this argument, should supply policies that are demanded by voters. ${ }^{2}$ But in order to assess whether these linkages exist, we obviously need to know the demand-side: what do voters want? And what determines these preferences?

Despite the importance of redistribution as government activity and for party competition, there is little systematic - and above all little comparative empirical research on the determinants of individual preferences. Given the amount of research devoted to models that rely heavily upon associations between individual characteristics and preferences (e.g. the literature on trade, on welfare states, on social stratification) this is puzzling. ${ }^{3}$

In order to explore the determinants of support for redistribution, this paper relies on public opinion surveys. Public opinion data are plagued by a variety of problems (see, e.g., Converse 1962, 1964; Page \& Shapiro 1992; Zaller 1992;

\footnotetext{
${ }^{1}$ This paper benefited from comments from and / or joint work with John Aldrich, Thomas Cusack, Lutz Engelhardt, Torben Iversen, Robert Keohane, Herbert Kitschelt, Moira Nelson, and David Soskice. I am very grateful for their - at times substantial - input. Remaining mistakes are mine. ${ }^{2}$ On the relationship between public opinion and public policy, see Papadakis 1992.

${ }^{3}$ One reason for this somewhat embarrassing lack of systematic comparative attitudinal research is the general scepticism toward public opinion research in political science (more on that below). Another reason is the overwhelming trend in political science to focus on institutions, not on tastes (Riker 1980).
} 
Hiscox 2003). While these problems should be kept in mind when drawing conclusions, there are also good reasons for the position that mass surveys do allow for meaningful causal inferences. For example, survey research replicates certain findings over and over again. Were survey answers merely statements drawn from "the top of the respondents' head" (Zaller 1992) and had no systematic component to them, this should not be the case. In addition, democracies are organized around the exact principle of meaningful preference articulation. However, this paper's premise - that comparative attitudinal research allows for meaningful causal inference - does not mean that there is a "grand theory" of social preference formation. In contrast, it is argued below that individual preferences are influenced by a variety of determinants.

In order to identify some of the determinants of support for income redistribution and assess their empirical utility, this paper proceeds as follows. In the next section, two logics of individual support for income redistribution are presented. The first logic - 'desire for equity' - assumes that people are in favor of income redistribution because they are disadvantaged. The second logic - 'desire for redistribution' - assumes that people are in favor of income redistribution because they want to insure themselves against certain risks that threaten their income stream. This framework is used to generate hypotheses about determinants of individual support for redistribution. The paper suggests a variety of new indicators measuring risk exposure at the individual level. The results are presented in section 3, and section 4 concludes. Details on the data can be found in the appendix. 


\section{Theory \& Hypotheses}

Support for income redistribution at the individual level is the object of interest in this study. The theoretical perspective that frames this paper suggests that two logics influence preference over income redistribution. The first logic - 'desire for equity' - comes in two forms. On the one hand, individuals may be in favor of income redistribution because they - selflessly - think this is a just principle. People's opinions, in this view, are "grounded in beliefs and values" (Peillon 1996: 178). On the other hand, individuals could be in favor of income redistribution because they - selfishly - see themselves as disadvantaged. This is the logic suggested by the famous Meltzer \& Richard (1981) model as well as in the power resource theory (Esping-Andersen 1985). Lack of data precludes dealing with the selfless version of the 'desire for equity' logic of preference formation. ${ }^{4}$ Instead, this paper will deal with the selfish kind of 'desire for equity' (redistribution for equity). From this perspective, the most important determinant of preferences over income redistribution is income: in a democracy, the maximum the disadvantaged can achieve is equity. Disadvantaged individuals, i.e. poor people, are in favor of income redistribution because they hope to gain from it.

The second logic of the formation of preferences over redistribution is a 'desire for insurance.' Individuals support income redistribution because it helps them to absorb income shocks and keep a certain minimum level of income even in bad times. They want to smooth their income over their life cycle. This perspective was most prominently formulated by Hal Varian. Under the assumption that future income is not completely certain ${ }^{5}$ he shows that "the motive for redistribution [...] is not a desire for equity per se, but rather a desire for social insurance" (Varian

\footnotetext{
${ }^{4}$ Indeed, studies have shown that, at least some of the time, "empirical beliefs about justice appear to be self-interested" (Hegtvedt 1992: 325). But see Peillon (1996).

${ }^{5}$ More concretely, an individual's actual income consists of his expected income plus a random error term (that is assumed to be uncorrelated between individuals). Under these conditions, "there is a clear economic case for the establishment of an insurance market which could eliminate individual risk" (Varian 1980: 51). However, it is not clear that insurance will be provided by a market. In contrast, many of the risks discussed in this paper are not insurable in the private market and, hence, need to be insured by the state.
} 
1980: 51, italics in original). ${ }^{6}$ Or, as Hans-Werner Sinn put it: "From an allocative point of view, the main advantage of the welfare state is the insurance or risk reducing function of redistributive taxation. [...] [G]overnments take more taxes from the rich than from the poor, thus reducing the variance in real lifetime incomes. [...] Redistributive taxation and insurance are two sides of the same coin" (Sinn 1995: 495-496). ${ }^{7}$ Redistribution, in other words, is desirable because it smoothes the income stream of individuals and shares the risk of income shocks across society. ${ }^{8}$

One can take the position that the two suggested logics of the formation of redistributional preferences are mutually exclusive. People either make up their mind relying on the calculus of equity or they form their opinions on income redistribution relying on the calculus of insurance. However, here it is argued that a synthetic view makes much more sense. Both logics of preference formation are important, and they are not mutually exclusive. ${ }^{9}$ Consequently, this paper hypothesizes that both logics influence preferences over income redistribution. However, the main focus is on the redistribution-as-insurance argument.

As was argued above, income arises as the most important determinant of the redistribution for equity logic. ${ }^{10}$ The paper explicitly controls for this logic in the estimated models. Hypotheses that can be derived from the redistribution-as-

\footnotetext{
${ }^{6}$ This perspective is also elegantly formulated in John Rawls' 'theory of justice' (Rawls 1971). When individuals have to decide behind a 'veil of ignorance', i.e. they are uncertain about their societal position, they opt for policies that support the least well-off.

${ }^{7}$ See also Andersen (2002), Arachi \& D’Antoni (2003).

${ }^{8}$ By providing insurance, redistribution also facilitates certain types of desirable investments, usually into human capital (see Iversen \& Soskice 2001).

${ }^{9}$ It may well be that these sources historically differed in their importance. One can argue that the redistribution for equity desire used to be - but is not anymore - more important than the redistribution-as-insurance desire. An explanation for the shift could be that societal demands changed because of an increase in individual (and societal) wealth. This is a similar mechanism as suggested by Wagner's law or in Ronald Inglehart's work. According to Ingelhart's "scarcity hypothesis", individuals have "need hierarchies" that influence their attitudes. According to his "socialization hypothesis", changes in need hierarchies occur slowly (Inglehart 1981: 881). Similarly, behavioral economists, most famously Kahneman \& Tversky (1979), consistently show that individuals change their perceptions (of gains and losses), depending on their reference point. It could well be that individuals nowadays primarily form their preferences according to the redistribution-as-insurance desire because the equity-desire is - at least in most countries analyzed in this paper - reasonably well met.

${ }^{10}$ The sociological literature suggests class or income as determinants; often, the former (class) is measured by the latter (income). See d'Anjou \& Steijn \& van Aarsen (1995: 357). Because it has been done elsewhere (Rehm 2004b), this paper does not deal with the class concept.
} 
insurance logic are presented below. Although it is theoretically well developed, the redistribution-as-insurance argument has not been tested in detail at the individual level. ${ }^{11}$ This is what this paper is about: to find out whether the insurance logic plays a substantive role in the formation of individual preferences over redistribution - even when controlling for the well established redistribution as equity logic.

\subsection{Dependent Variable}

In order to test the empirical utility of the redistribution-as-insurance argument, this paper's dependent variable is “support for income redistribution", or, simply put, redistributional preferences. More concretely, people were asked the following question: ${ }^{12}$

"Please say to what extent you agree or disagree with the following statement: The government should take measures to reduce differences in income levels.”

The five possible answer categories and their frequencies are shown in the graph below. The scale goes from 1 (“agree strongly") to 5 (“disagree strongly"). The (weighted or unweighted) mean of the measure is 3.75 (with a standard deviation of roughly 1), i.e. more respondents are in agreement with the statement than in disagreement. ${ }^{13}$

\footnotetext{
${ }^{11}$ There are a few exceptions, such as Iversen \& Soskice 2001. A "sociological version" has been tested by Taylor-Gooby et al. 1999.

${ }^{12}$ In this paper, the European Social Survey [ESS] 2002/2003 is employed; for details, see below.

${ }^{13}$ Means, standard deviations and number of observations for each country are listed in the appendix in table 3 .
} 
Government should reduce differences in income levels

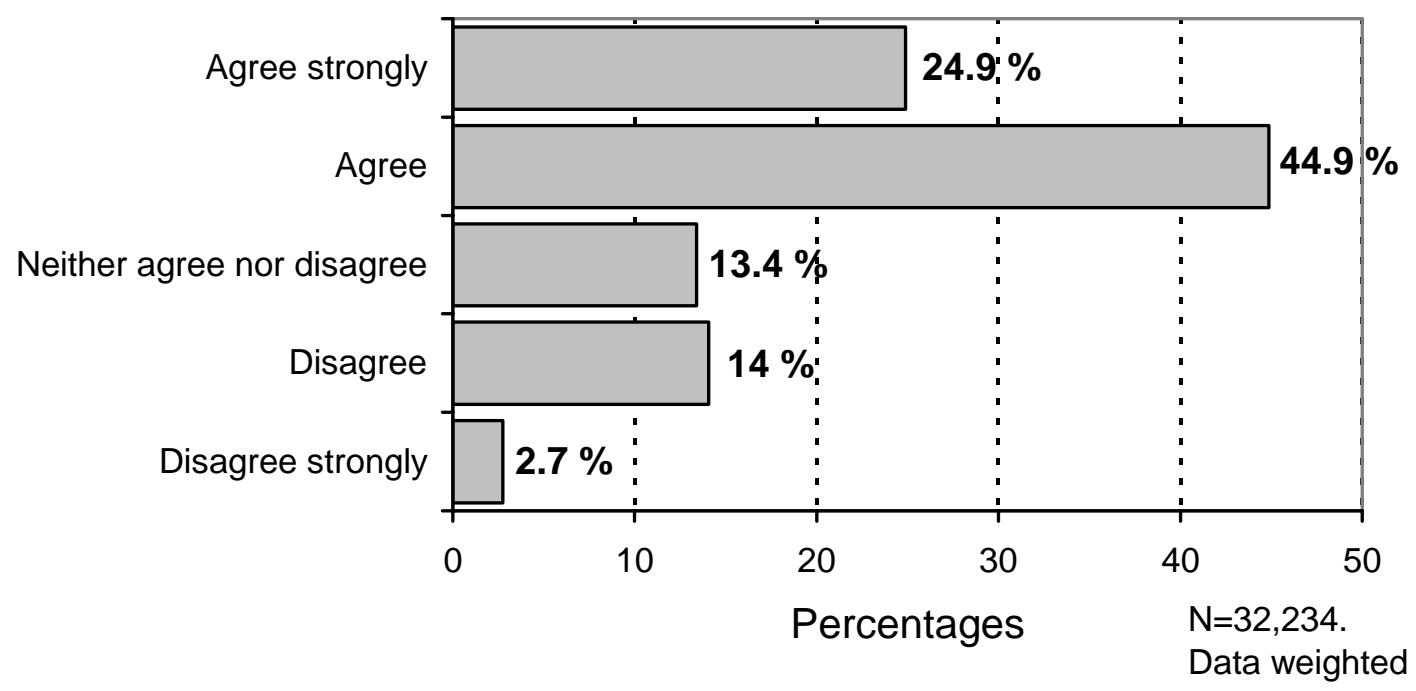

The following table shows the mean, standard deviation and number of observation of the dependent variable for each country in the sample.

\begin{tabular}{lccc}
\hline 'Government should reduce differences in income levels' & $\begin{array}{c}\text { Weighted Mean } \\
\text { (sorting variable) }\end{array}$ & Standard Deviation & $\begin{array}{c}\text { Number of } \\
\text { Observations }\end{array}$ \\
\hline Denmark & 2.98 & 1.16 & 1,403 \\
\hline West Germany & 3.16 & 1.09 & 1,736 \\
\hline Netherlands & 3.39 & 1.05 & 2,340 \\
\hline United Kingdom & 3.48 & 1.02 & 2,022 \\
\hline Switzerland & 3.52 & 1.04 & 2,005 \\
\hline Luxembourg & 3.59 & 1.19 & 1,444 \\
\hline Sweden & 3.67 & 0.93 & 1,947 \\
\hline Norway & 3.71 & 0.93 & 2,030 \\
\hline Belgium & 3.73 & 1.06 & 1,861 \\
\hline Austria & 3.74 & 1.11 & 2,136 \\
\hline & & & $\mathbf{3 2 , 2 3 4}$ \\
\hline All countries & 3.75 & $\mathbf{1 . 0 6}$ & 1,977 \\
\hline & & & 1,140 \\
\hline Ireland & 3.80 & 0.91 & 1,973 \\
\hline East Germany & 3.87 & 0.95 & 1,606 \\
\hline Finland & 4.00 & 1.04 & 1,489 \\
\hline Spain & 4.02 & 0.86 & 1,500 \\
\hline Italy & 4.04 & 0.93 & \\
\hline France & 4.16 & 1.03 & 0.75 \\
\hline Greece & 4.32 & 0.69 & \\
\hline Portugal & 4.33 & & \\
\hline
\end{tabular}


Since the interpretation of the estimation-results is significantly facilitated by a binary operationalization of the dependent variable, usually a transformed variable is employed. ${ }^{14}$ Its distribution is shown in the following graph:

\section{Government should reduce differences in income levels}

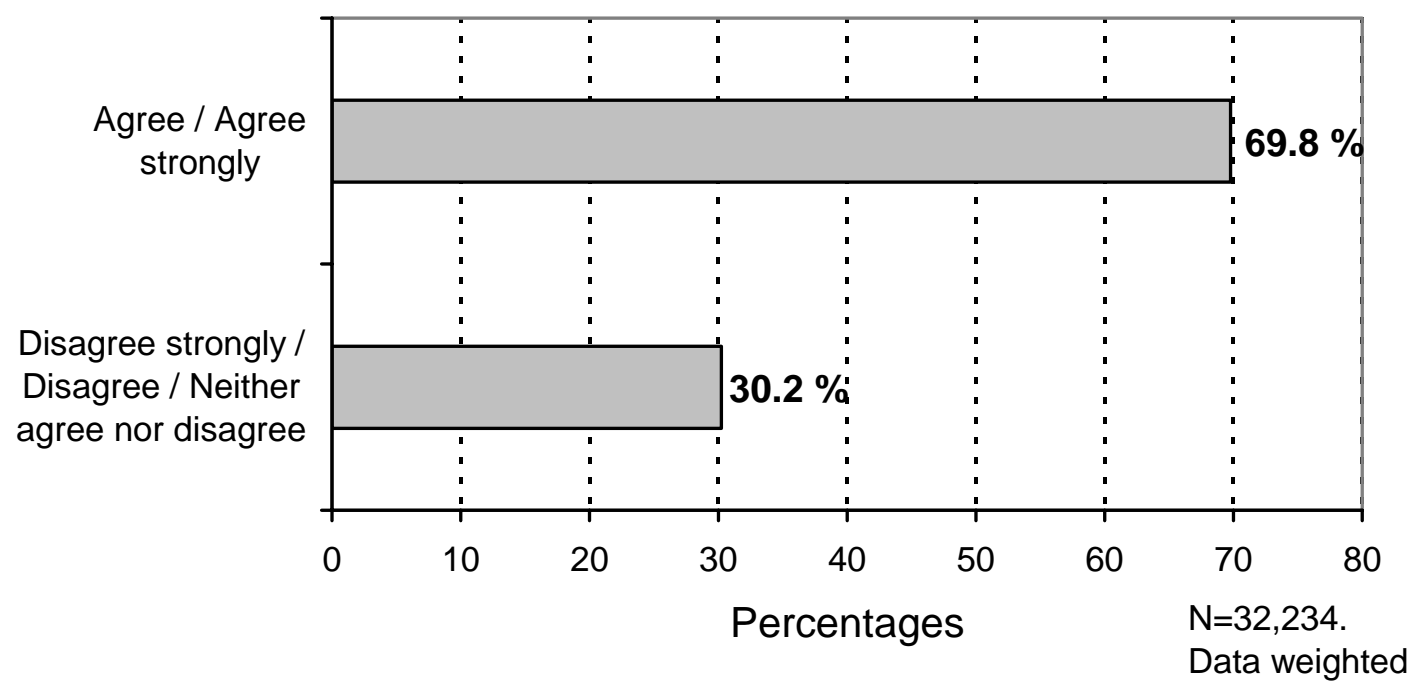

The ultimate test for the quality of a dependent variable is whether it fits the underlying concept well. As is typical in the survey literature, the above mentioned question is not perfect. On the positive side, the question is broad enough to cover the redistribution for equity and the redistribution-as-insurance dimension: "Measures to reduce differences in income levels" can include mere Robin-Hoodstyle redistribution (taking from the rich and giving to the poor) as well as more subtle redistributional arrangements that insure against certain risks. In addition, the question is parsimonious in terms of the stimuli it provokes. ${ }^{15}$ Since citizens typically hold competing values, "the considerations they care about can come into conflict in particular situations" (Sniderman \& Brody \& Tetlock 1991: 52). Framing a question in a certain way can establish the salience of one consideration over the other. In particular, the question does not remind respondents that "measures to reduce differences in income levels" result in higher taxes. This avoids a "taxation

\footnotetext{
${ }^{14}$ For robustness tests, sometimes the original five-point measure is employed.

${ }^{15}$ The argument goes parallel to John Zaller's (1992) theory of how people make up their answers to survey questions. There, two-sided information flows provide more than one stimulus. It is very tricky to deal with this phenomenon because "dominant and countervalent messages can have different effects in different segments of the population, depending on citizens' political awareness and ideological orientations and on the relative intensities of the two messages" (1992: 185).
} 
stimulus' - unlike the question wording on similar issues in other surveys. ${ }^{16}$ This could also explain why the overall support for redistribution is so high. On the negative side, the question's parsimony is also problematic. Obviously, it would be desirable to have several and very detailed questions asking about different aspects of redistribution, in particular about the insurance aspect of redistribution. ${ }^{17}$ In addition, it is not clear how the status quo comes into the picture. Does the question ask for a general opinion (à la 'in general, do you think governments should take measures...') or a very specific opinion (à la 'given the status quo in your country, should the government take more or less measures...'). Taken together, the above mentioned question is of reasonable quality. ${ }^{18}$

\subsection{Independent Variables}

This paper's main focus is on the empirical utility of the redistribution-asinsurance argument, controlling for the redistribution for equity logic. Taking existing political-economy theories as the starting point, the paper derives several hypotheses about the impact of certain risk factors on individual preferences over redistribution. These factors center on the risk of losing income as a consequence of adverse labor market dynamics. First, variables related to this argument are discussed. Then, the control variables are presented.

\subsubsection{Risk of unemployment}

One implication of the redistribution-as-insurance logic is the following causal mechanism: For most people, employment is the main source of income (see Beramendi \& Cusack 2004 for comparable numbers on the importance of wages for the personal disposable income). The most direct threat to this primary source of income is losing one's job. In the spirit of understanding redistribution as a means to insure against risks, the risk of unemployment should influence preferences over redistribution. Ceteris paribus, the higher the risk of unemployment, the more an individual favors redistribution. The risk of unemployment is a function of many

\footnotetext{
${ }^{16}$ For example, it would be much more difficult to argue that the following hypothetical question covers both sources of preference formation: "Are you in favor of taking income from the rich and giving it to the poor?"

${ }^{17}$ Unfortunately, no international survey exists that has these detailed policy questions and the necessary key independent variables at the same time.

${ }^{18}$ Especially since the country fixed-effects in the estimations control for systematic biases across countries and since there is no reason to believe that there other non-random patterns in the data.
} 
factors, and it is difficult to measure. This paper relies on existing political economy theories to identify some factors that are likely to influence the risk of unemployment. In particular, the following conditions are argued to increase the risk of unemployment: unfavorable structural change, international incompetitiveness, specific skills, and employment in occupations with unfavorable futures. Each of these is discussed in turn.

\section{Structural change}

Labor markets are dynamic. Certain industries prosper, while others decline. For example, the service sector grew, whereas the agricultural and industrial sectors declined in most countries over the last decades. Following the logic that individuals demand social policy to insure against risks, it is hypothesized that one's employment risk influences one's preferences over redistribution:

Individuals employed in industries (sectors) that suffer from job-losses are over-proportionally in favor of redistribution.

In order to judge the impact of structural change on individual preferences, we need a fine-grained measure of structural change that does not lump together different sectors ${ }^{19}$ and their development. The risk of unemployment brought by structural change should be measured by looking at employment dynamics at a detailed sectoral level. Therefore, this paper uses a variable from the European Social Survey [ESS] that contains detailed information on sectoral employment (in the NACE Revision 1 classification, 2-digit). ${ }^{20}$ At this level of detail, the classification distinguishes 60 different industries. ${ }^{21}$ EU labor force data containing information on the employment dynamics of these 60 different sectors are merged into the dataset, differentiating by gender. The resulting measure of structural change has up to 120 different values, for each country, for various years. ${ }^{22}$

\footnotetext{
${ }^{19}$ Sector and industry are used interchangeably.

${ }^{20}$ The "Statistical Classification of Economic Activities in the European Community (NACE, Revision 1)" can be found here: http://europa.eu.int/comm/eurostat/ramon/nomenclatures/index.cfm?TargetUrl=LST_NOM_DTL_L INEAR\&IntCurrentPage $=1 \&$ StrNom=NACE_1_1\&StrLanguageCode=EN.

${ }^{21}$ For example, NACE 2-digit code 30 stands for "manufacture of office machinery and computers", whereas code 70 is assigned to people that are involved in "real estate activities."

${ }^{22}$ Please see the appendix for details.
} 


\section{International competition}

The literature on international competition and its potential effect on (un)employment and individual preferences is vast and detailed. The comparative political economy as well as the international political economy literature relies on arguments that connect an individual's sectoral employment with her preferences. Theoretically, this link has been developed in some detail, especially in the trade literature. For example, the Stolper-Samuelson theorem - or variants thereof predicts that people employed in a sector enjoying a comparative advantage will have systematically different preferences than those in sectors with comparative disadvantage or in non-tradable sectors (Frieden 1991: 451; Mayda \& Rodrik 2002). A somewhat comparable logic has been brought forward in the welfare state literature. There, the stylized fact that small, export-dependent countries tend to have large welfare states has been explained with the so-called compensation hypothesis (Cameron 1978; Katzenstein 1985: 47-57; Rodrik 1998). The proposed logic is that exposure to international competition increases workers' insecurity, for which they are compensated with generous social security benefits. ${ }^{23}$ Although the compensation hypothesis is usually applied to macro-units, namely countries, it has to have a micro-logic - in some accounts this is made explicit: "[.] if the government acts as the agent of households that dislike risk, it will choose to consume a greater share of the society's resources in economies that are subject to greater amount of external risk" (Rodrik 1998: 1011). ${ }^{24}$ Relatedly, the literature on welfare state retrenchment suggests that intensified international competition leads to political conflicts between workers and employers in the exposed sectors on the one hand and those in sheltered (usually public) sectors on the other hand: "workers and employers in exposed sectors become acutely concerned with containing the upward pressure on domestic costs generated by large public sectors. In this context a new political-economic cleavage between sheltered and exposed sectors opens up

\footnotetext{
${ }^{23}$ Note that this argument rests on the assumption that increased trade exposure actually increases risks (see Manow 1999).

${ }^{24}$ Although Rodrik refers in this quote to government consumption, he explicitly states that the equivalent insurance function in OECD countries is usually provided by "the establishment of a safety net" because they "do have the administrative capacity to manage social welfare systems" (Rodrik 1998: 1012).
} 
and the exposed sector coalition exerts increasing pressure for public sector reform" (Clayton \& Pontusson 1998: 97). ${ }^{25}$

Although these theories rely on causal mechanisms at the individual level, and despite their importance, they have hardly been tested at the micro-level. ${ }^{26}$ This paper offers tests of some of these arguments. In particular, the following hypotheses are derived from the above mentioned arguments and tested below:

Individuals employed in sectors that are exposed to international markets (i.e. trade) hold different preferences than people in sectors that are not exposed to trade. More concretely, individuals employed in sectors that enjoy a comparative advantage are less in favor of redistribution than individuals in the non-tradable sector or sectors that suffer from a comparative disadvantage.

For testing these hypotheses, the survey variable that contains sectoral employment information at NACE (2-digit level) can be employed again. Information about a sector's exposure to trade (tradable sector or not) are merged into the data-set. If a sector does trade, its comparative advantage or disadvantage is computed, using OECD's “International Trade by Commodity Statistics (ITCS).,27

\section{Specific Skills}

Torben Iversen \& David Soskice (2001) propose to consider the 'skill specificity' as an important variable that determines individual preferences over redistributive policies (see also Estevez-Abe \& Iversen \& Soskice 2001; Moene \& Wallerstein 2001). In their seminal article "An Asset Theory of Social Policy Preferences", they develop an explanation for preferences over redistribution that emphasizes the composition of individuals' skills. The crucial causal mechanism that they propose is that individuals who have made risky investments (i.e. investments in specific skills) "will demand insurance against the possible future loss of income from those investments" (Iversen \& Soskice 2001: 875). The assumption underlying this logic is that acquired human skills can be understood as investment (Becker 1964). In following Williamson's transaction cost theory

\footnotetext{
${ }^{25}$ This 'cleavage' has been identified before: "Confronted with the cleavage between externally oriented and domestically oriented economic sectors, the small European states have developed corporatist structures that enhance political predictability by facilitating cooperation and compromise" (Katzenstein 1985: 96). See also Rieger \& Leibfried (1998).

${ }^{26}$ Only very recently, the trade literature turned to empirical investigations of the underlying micrologic of its theories (see Mayda \& Rodrik 2002; O'Rourke \& Sinnott 2001; Scheve \& Slaugther 2001), with mixed results.

${ }^{27}$ Please see the appendix for details.
} 
(1985), Iversen \& Soskice (2001) argue that non-market institutions such as redistribution can overcome market failures such as under-investment in specific skills. In terms of human capital, market failure would prevent investment in specific skills because individuals with specific skills could not market them elsewhere. This exposure to risk "is inversely related to the portability of skills" (Iversen \& Soskice 2001: 875). More concretely, general skills are marketable within the whole economy whereas specific skills are marketable only in one sector (Iversen \& Soskice 2001: 875).

Their model's most general and key testable implication is that "workers with specific skills will prefer higher taxes and social protection than workers with general skills", or, to put it even differently: "skill specificity increases the demand for social protection" (Iversen \& Soskice 2001: 879, 880). This is the next hypothesis:

Individuals with more specific skills demand more redistributional policies.

For testing this hypothesis, the paper relies on a similar operationalization as proposed in the original article (Iversen \& Soskice 2001: 881-883). For reasons of data-reliability, there is one difference: what is called "the size of the labor market segment" of each occupation (p. 881) is not measured within the survey itself but with EU labor force data (as the mean of all countries used in the analyses, 19972002). ${ }^{28}$

\section{Disadvantaged occupations}

Some occupations appear to be particularly exposed to the changing vagaries of dynamic labor markets. People in these occupations should be especially worried about their jobs. This is the next hypothesis:

Individuals in disadvantaged occupations (i.e. occupations with high unemployment rates) are more in favor of redistribution than individuals in advantaged occupations (i.e. occupations with low unemployment rates).

This is the most direct test of the redistribution-as-insurance argument in this paper: the link between occupational unemployment and the assumed causal mechanism (risk of unemployment influences redistributive preferences) is close. In order to

\footnotetext{
${ }^{28}$ Please see the appendix for details.
} 
test the hypothesis, occupational unemployment rates were merged with a survey variable that contains detailed occupational information. As a result, the study employs unemployment rates at the 3-digit level of the "International Standard Classification of Occupations (ISCO88)” classification, exploiting EU labor force survey data. There are up to 108 unemployment rates per country. ${ }^{29}$

\subsubsection{Control Variables}

In order to investigate the empirical performance of the determinants of individual preferences over redistribution, it is important to carefully consider other factors that potentially influence these preferences. Unless there are good reasons not to, the following standard control variables are included in the estimations:

\section{Income}

Income is the variable that controls for the redistribution-as-equity argument: the wording of the question used as dependent variable suggests that redistribution is progressive ${ }^{30}$ ("Please say to what extent you agree or disagree with the following statement: The government should take measures to reduce differences in income levels"). As argued above, this reasoning is in line with the widely used Meltzer-Richard model (Meltzer \& Richard 1981). There, voters with incomes above the mean income will demand less redistribution than voters with incomes below the mean (this hypothesis will be tested in passing). In addition, income is an important control variable because it influences the ability of individuals to insure themselves against fluctuations of their income stream, for example by saving. Rich individuals do not need the insurance provided by redistribution, because they can insure themselves. ${ }^{31}$

Age

Age may influence preferences over redistribution in several ways. To begin with, older people tend to be more dependent on health insurance and pensions. In

\footnotetext{
${ }^{29}$ For the analyses, ISCO88 2-digit category “11” (legislators and senior officials) was usually excluded because the data-quality for this very small group is low. The results are not affected by this in any way. Please see the appendix for details.

${ }^{30}$ However, it is not a priori true that the rich pay the bill for the welfare state. For example, Lindert (2004) argues that different social policies have very different distributional logics. Big welfare states tend to be financed by a variety of taxes. Huge revenues are derived from value added taxes (VATs), which are not progressive.

${ }^{31}$ Even if they do not pay an over-proportional share of the burden, their ability to insure themselves may be reduced by state intervention, because the disposable income is reduced.
} 
most countries within the sample, these are financed by state-funded, redistributive schemes. Secondly, "older workers are likely to be more concerned with job security and income than younger workers" (Iversen \& Soskice 2001: 883), because they are less likely to find another job should they lose their present one.

\section{Gender}

That there are systematic attitudinal differences between women and men is a very consistent and badly understood phenomenon. With regard to redistributional preferences, a potential explanation that stresses the importance of the labor market could argue that women have to move into and out of the labor market more often than men. This is so mainly because women still shoulder the major burden of child rearing and care of frail parents. In addition, women's jobs are over-proportionally dependent on the welfare state itself (i.e., they hold an over-proportional share of public sector service jobs). As a final reason, one can argue that women's higher life expectancy gives them more favorable preferences for redistributive schemes (pensions, health care, etc.).

\section{Education}

Education is a somewhat problematic control variable. Sometimes, it will be excluded because it covaries with some of the key independent variables. The risk of occupational unemployment, for example, negatively correlates with education. The operationalization of skill specificity, as another example, explicitly controls for education. Nevertheless, education influences life-chances and income opportunities and, therefore, qualifies as an important control variable.

\section{Self-employment}

The self-employed often employ others. That means that they depend on "flexible labor markets and often on relatively low-paid workers." One could expect, then, that they are in favor of "free markets and a low level of social protection" (Iversen \& Soskice 2001: 883). Therefore, the self-employed are expected to be less supportive of income redistribution than individuals who are not self-employed. 


\section{Union membership}

Since unions are meant to provide insurance against risks related to the workplace, including redistributional policies, controlling for union membership is necessary. In addition, it can be shown that union members self-select into union because they hold strong social-protectionist views (Kitschelt \& Rehm 2004a).

\section{Unemployed}

Straightforwardly, the unemployed are expected to support high levels of redistribution, because they depend on transfers.

These control variables are very common in comparative attitudinal research. ${ }^{32}$

\section{Data \& Results}

\subsection{Data}

The data-set employed in this paper is the European Social Survey [ESS] 2002/2003 33 (Jowell \& Central Co-ordinating Team 2002/2003). The ESS is funded jointly by the European Commission, the European Science Foundation and scientific funding bodies in each of the 22 participating country. The ESS is the only cross-country survey that has comparable variables on industry employment and occupation, which is necessary for testing the hypotheses formulated above. In

\footnotetext{
${ }^{32}$ Of course, the list of control variables could be extended. In what follows, some relatively common control variables that are not included in this study are briefly discussed.

- Transfer dependence Individuals relying on state transfers are, obviously, expected to be supportive of these transfer schemes and, hence, redistribution. But since this feedback-loop argument - prominently put forward by Paul Pierson $(1994,1996)$ - turns out not to be important (see below), transfer dependence will not be a standard control variable.
}

- $\quad$ Nonemployed, part-time employed These variables have been included, for example, in Iversen \& Soskice (2001). Two reasons speak against including them as standard control variables. First, the categories of the nonemployed and part-time employed are very heterogeneous. People are for very different reasons not employed, and they work for very different reasons only part-time. Second, these variables empirically turn out not to be important.

- $\quad$ Left-right position

Unfortunately, it is quite common to include left-right self-placement (or similar party affiliation variables) as independent variables in models predicting preferences. While this may make sense under very restrictive circumstances, generally it does not. These variables are almost certainly endogenous: being left or right means supporting redistribution or not (Kitschelt \& Rehm 2004a). In addition, it is usually trivial to predict attitudes (e.g. redistribution) with other attitudes (such as leftright self-placement) - of course they covary!

${ }^{33}$ The fieldwork was carried out between September 2002 and December 2003, but on average within four months in each country. 
terms of quality, the ESS is the best available cross-country survey that has ever been published.

Data on the following 17 countries are analyzed: Austria, Belgium, Denmark, Finland, France, Germany (East and West separately), Greece, Ireland, Italy, Luxembourg, the Netherlands, Norway, Portugal, Spain, Sweden, Switzerland, and the United Kingdom. There are two reasons for excluding the Czech Republic, Israel, Hungary, Poland and Slovenia. On the one hand, most data that are merged into the survey are not available for these countries. On the other hand, it is reasonable to select countries that are at least roughly comparable and, therefore, meet basic unit homogeneity assumptions. Unlike the 17 selected countries, the five excluded countries cannot be counted as advanced capitalist democracies.

\subsection{Estimation Strategy}

A series of probit models are estimated, based on the following general model: ${ }^{34}$

$$
\text { Preferences for redistribution }=\beta_{0}+\beta_{1}^{*} I V+\sum_{i=2}^{I} \beta_{i}+\varepsilon
$$

where "IV" is the independent variable of interest - they vary across the models and $\beta_{\mathrm{i}}(\mathrm{i}=2,3, \ldots, \mathrm{I})$ are the coefficients for control variables, including country dummies. The residuals, $\varepsilon$, are assumed to be identically and independently distributed. This is a standard specification for models using survey data. For all estimations, data are weighted. ${ }^{35}$ All equations have been estimated with STATA 8.

\subsection{Results ${ }^{36}$}

In interpreting the results, the focus will be on three characteristics of the estimated coefficients: their statistical significance, their substantive effect, and their robustness. Statistical significance asks whether the estimated coefficient is statistically significant from zero, at usual statistical significance levels.

\footnotetext{
${ }^{34}$ For robustness, models are sometimes estimated as ordered probit and probit models.

${ }^{35}$ Following the ESS documentation, the design weight (correcting for the probability of being selected, variable "dweight") is multiplied with the population weight (adjusting the sample size to the country size, variable "pweight"). For estimations involving only one country, only design weights are employed.

${ }^{36}$ To economize on space, country dummies are neither shown nor discussed.
} 
Considering a coefficient's substantive effect is the best way to get a sense of a variable's effect on a categorical dependent variable. ${ }^{37}$ In order to evaluate the substantive effect of the variables, this paper heavily relies on simulations.

Simulations reveal the impact of one variable on the dependent variable, holding everything else constant. For example, simulations can show how the dependent variable (i.e. preferences over income redistribution) of a hypothetical individual changes when one increases this individual's education. Equivalently, one can think about simulations in the following way: how are the preferences different from two individuals that are identical but differ on the variable of interest? Therefore, simulations help to visualize and evaluate the impact of the independent variable of interest on the dependent variable. This impact is called the variable's substantive effect. Finally, the paper considers the robustness of coefficients. It is impossible to define a clear decision rule for a coefficient's robustness. Here, coefficients are said to be robust if they are statistically significant in a variety of models. Models can differ, for example, in their specifications, ${ }^{38}$ on the sample they are tested, ${ }^{39}$ and in the way variables are operationalized. ${ }^{40}$ Details can be found in the appendix. Although there are neither clear rules for what constitutes a meaningful 'substantive effect' nor what can be seen as a 'robust' relationship, this paper discusses these concepts. Considering the three characteristics - statistical significance, substantive effect, and robustness - should increase the reliability of the results.

\subsubsection{Baseline Model}

Table 1 shows the results of the baseline-model, i.e., the regression model with the control variables alone and no variables of substantive interest. By and large, except for the coefficient on age the results are in line with the expectations. All theorized coefficients are significant, point in the right direction and, as will be shown shortly, have a non-negligible substantive effect. This pattern holds for the ordered probit as well as the probit estimation results (table 1, models 1 and 2).

\footnotetext{
${ }^{37}$ For many of the substantive effects simulations, the software SPost (Long \& Freese 2002) is used. ${ }^{38}$ For example, by excluding control variables.

${ }^{39}$ For example, by excluding one country at a time (Jackknife tests).

${ }^{40}$ For example, the occupational unemployment variable is measured at different time points and at different levels of detail. Each of these variables (and averages thereof) are estimated.
} 


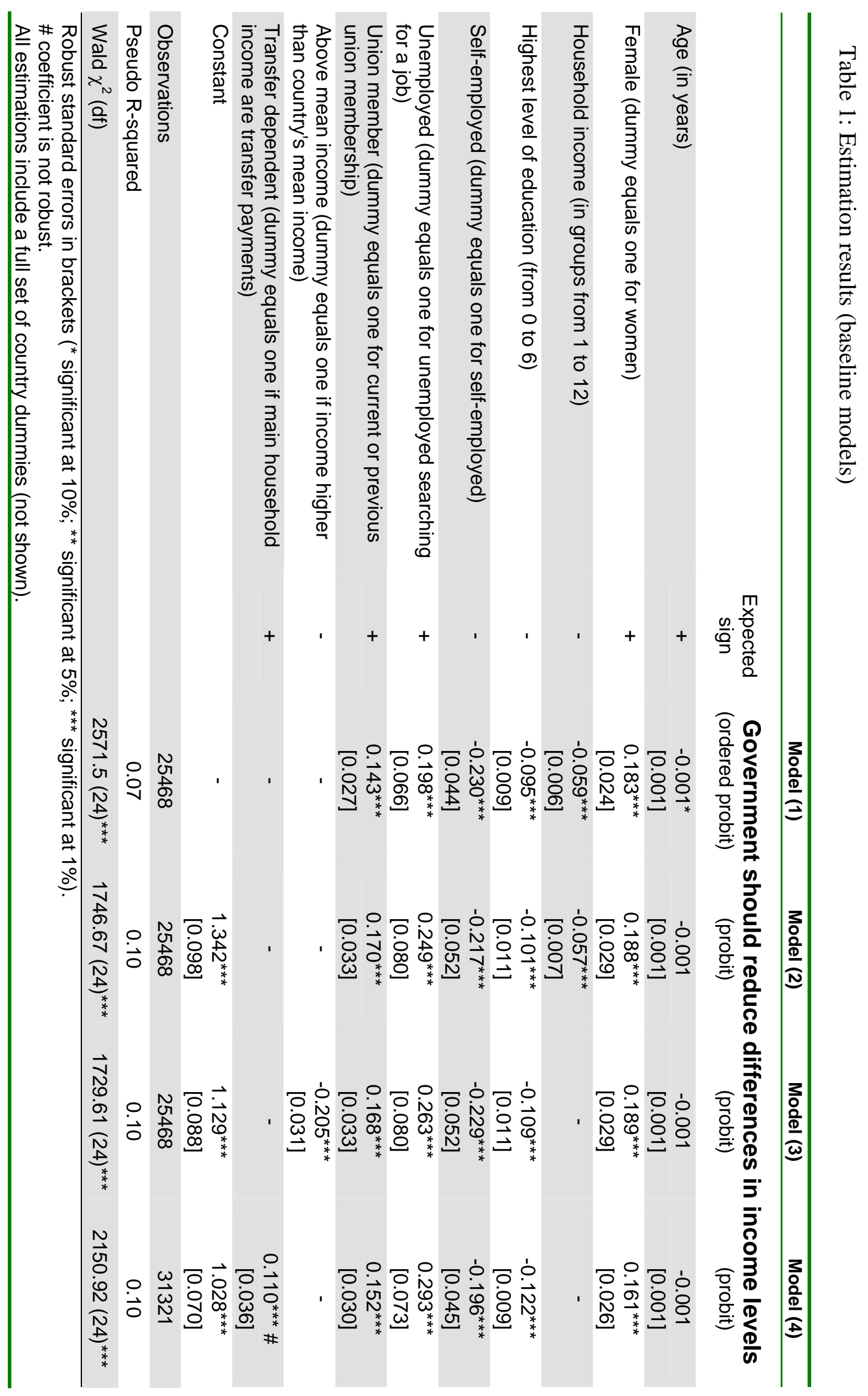


When using categorical dependent variables it is even more difficult than in models with continuous dependent variables to evaluate the overall fit of the estimated model. The table provides "Pseudo- $\mathrm{R}^{2 \text { ' }} \mathrm{s}$ " for every reported estimation as well as Wald statistics. The latter allows for testing the hypothesis that all coefficients except the intercept are zero (this hypothesis is rejected in all models). As a third possibility, the percentage of correctly predicted observations (PCP) for the baseline model shall be presented. Although this measure suffers from various problems (see Hagle \& Mitchell II 1992; Herron 1999), it is nevertheless displayed in the following table. ${ }^{41}$ As can be seen from the table, the baseline-model predicts $72.2 \%$ of the observations correctly. ${ }^{42}$

\begin{tabular}{cccc}
\hline \multicolumn{4}{c}{ Correctly and incorrectly predicted observations } \\
\hline \multicolumn{4}{c}{ Observed } \\
\hline Predicted & 0 & 1 & Total \\
\hline 0 & $\begin{array}{c}1,555 \\
(6.1 \%)\end{array}$ & $\begin{array}{c}1,103 \\
(4.3 \%)\end{array}$ & 2,658 \\
\hline \multirow{4}{*}{1} & $\begin{array}{c}5,977 \\
(23.5 \%)\end{array}$ & $\begin{array}{c}16,833 \\
(66.1 \%)\end{array}$ & 22,810 \\
\hline \multirow{4}{*}{ Total } & 17,936 & 25,468 \\
\hline \multicolumn{4}{c}{7,532} \\
\hline Percent correctly predicted: 72.2 \% \\
Modal category: 70.4 \%
\end{tabular}

The following graphs show the substantive effect of all significant control variables in the baseline-model (table 1, model 2). The combination of variables shown in the graphs neither follows a particular logic nor changes the findings in any way. Showing the simulated substantive effects of two variables at the same time simply economizes on space. The first graph shows the substantive effect of income on preferences over redistribution, by gender. ${ }^{43}$ More concretely, the graph visualizes the effect of income on support for redistribution by means of two lines: one for women

\footnotetext{
${ }^{41}$ The cut-off point was set at 0.5 .

${ }^{42}$ It is difficult to evaluate whether this qualifies as a 'good' or a 'bad' model, but the table shows that the model is at least more successful than a simplistic model that trivially predicts that all observations will be a one. By design, such a model correctly predicts all observed ones in the data-set (here: 70.4\%; see "modal category" in the table). The "reduction in error", i.e. the proportion of correct guesses beyond the number that would be correctly guessed by choosing the modal category, is $6.1 \%$ (see Long \&

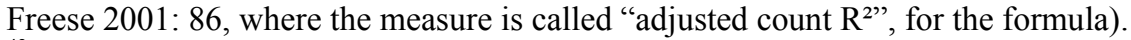

${ }^{43}$ Unless otherwise noted, for the simulations all continuous variables are set to their (unweighted) mean and all dummy variables to zero.
} 
(the dashed line), the other one for men. As can be seen from the graph, there is a gender gap: women are generally more in favor of redistribution (regardless of the income level). As can be read from the distance between the two lines, women's probability of agreeing or strongly agreeing with redistribution is around $6 \%$ higher than the probability for men. For example, the probability that an "average man" 44 is in favor of income redistribution is around $73 \%$. The same value for an "average woman", then, is six percentage points higher, i.e. $79 \%$. The graph also shows that income has a huge substantive effect. Hypothetically changing the income level of an "average individual" from lowest $(=1)$ to highest $(=12)$ decreases this individual's probability of being in favor of income redistribution by roughly $20 \%$. For example, the probability of being in support for redistribution for a man with lowest income is around $82 \%$. The probability of the same hypothetical man drops to around $62 \%$ when one simulates a change in income to the highest income level.

GRAPH 1: Substantive effect of income on preference for redistribution, by gender

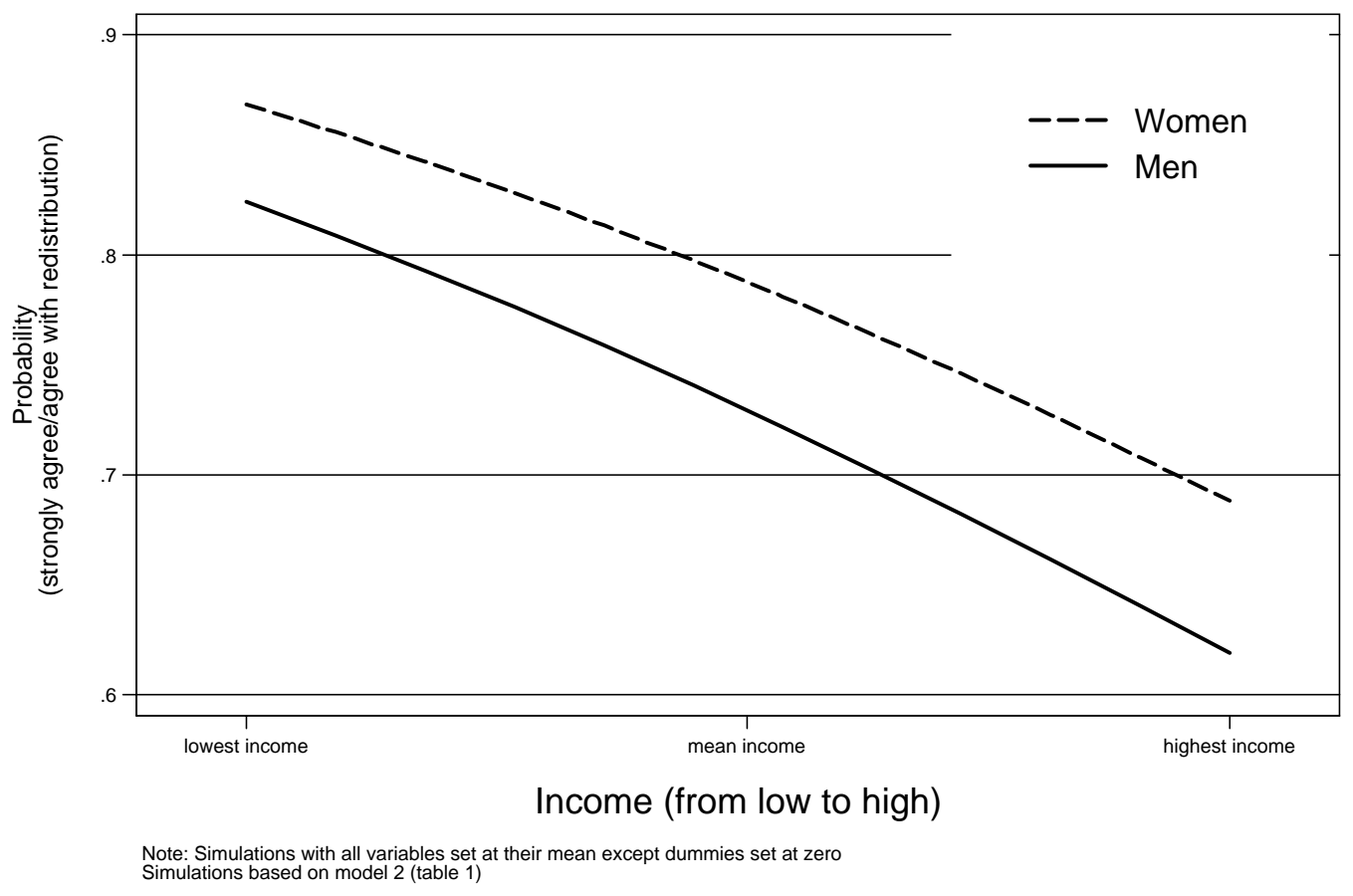

\footnotetext{
${ }^{44}$ The "average man" has mean income, age, and educational level, is dependent employed, not unemployed, and not a union member. He comes from no country.
} 
Likewise, education plays an important role in shaping preferences over income redistribution (see graph 2). Changing educational level from lowest (0) to highest (6) decreases the probability of being in favor of income redistribution by roughly $20 \%$. As can be also seen from graph 2, self-employed individuals are less in favor of income redistribution than people who are not self-employed. The distance between the dotted and the solid line indicates that the probability of being in favor of redistribution of a person not self-employed is almost $8 \%$ higher than the probability of a self-employed individual.

GRAPH 2: Substantive effect of education on preference for redistribution, by selfemployment

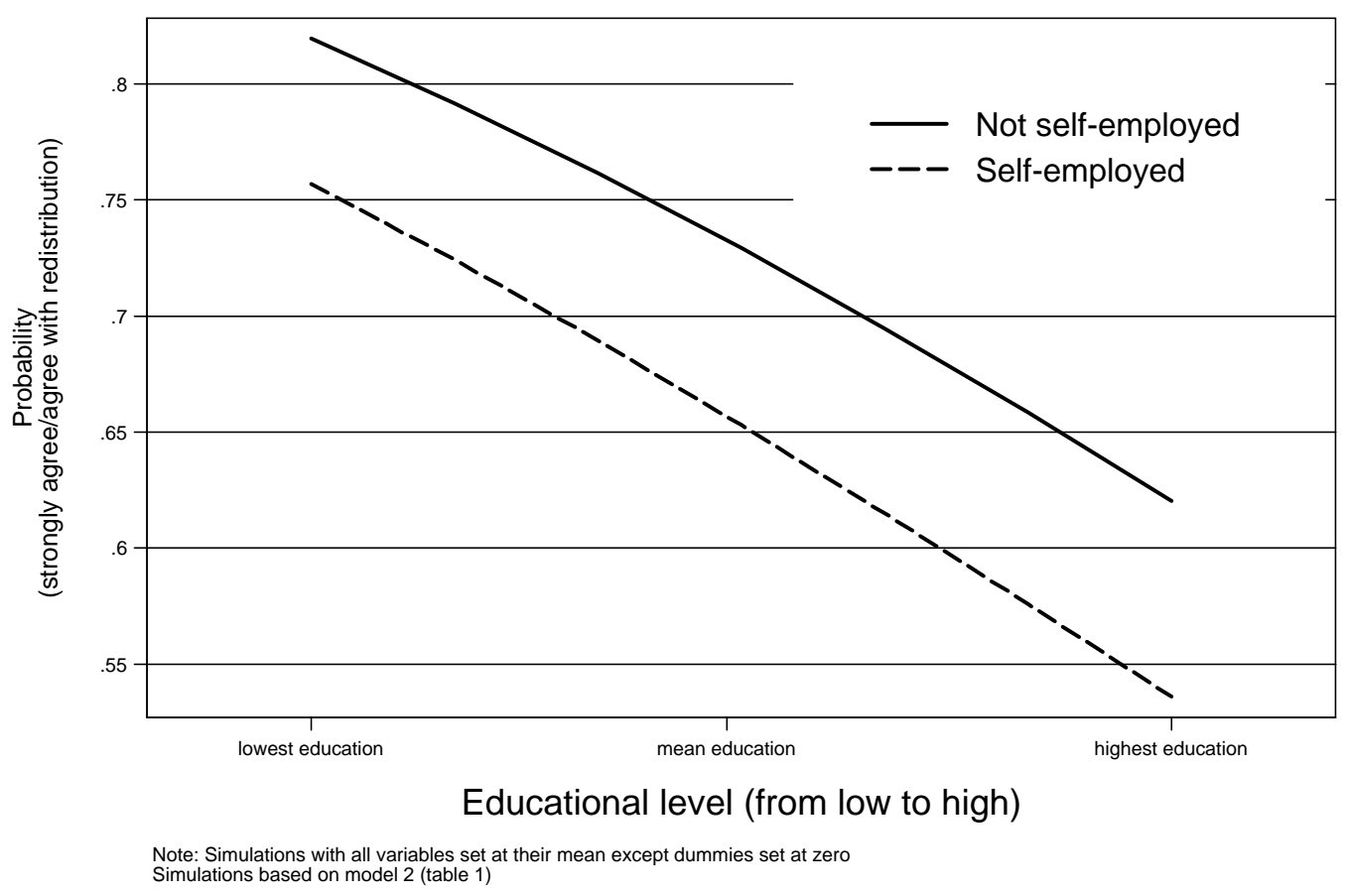

The third graph shows the simulation for unemployment and union membership.

On the left side of the graph, on can see that being unemployed increases an individual's probability of agreeing with redistribution from $73 \%$ to above $80 \%$. The substantive effect of union membership is smaller. As can be read from the two bars at the right side of graph 3, union membership increases the probability of being in favor of income redistribution by around $5 \%$. 
GRAPH 3: Substantive effect of union membership and unemployment on preference for redistribution

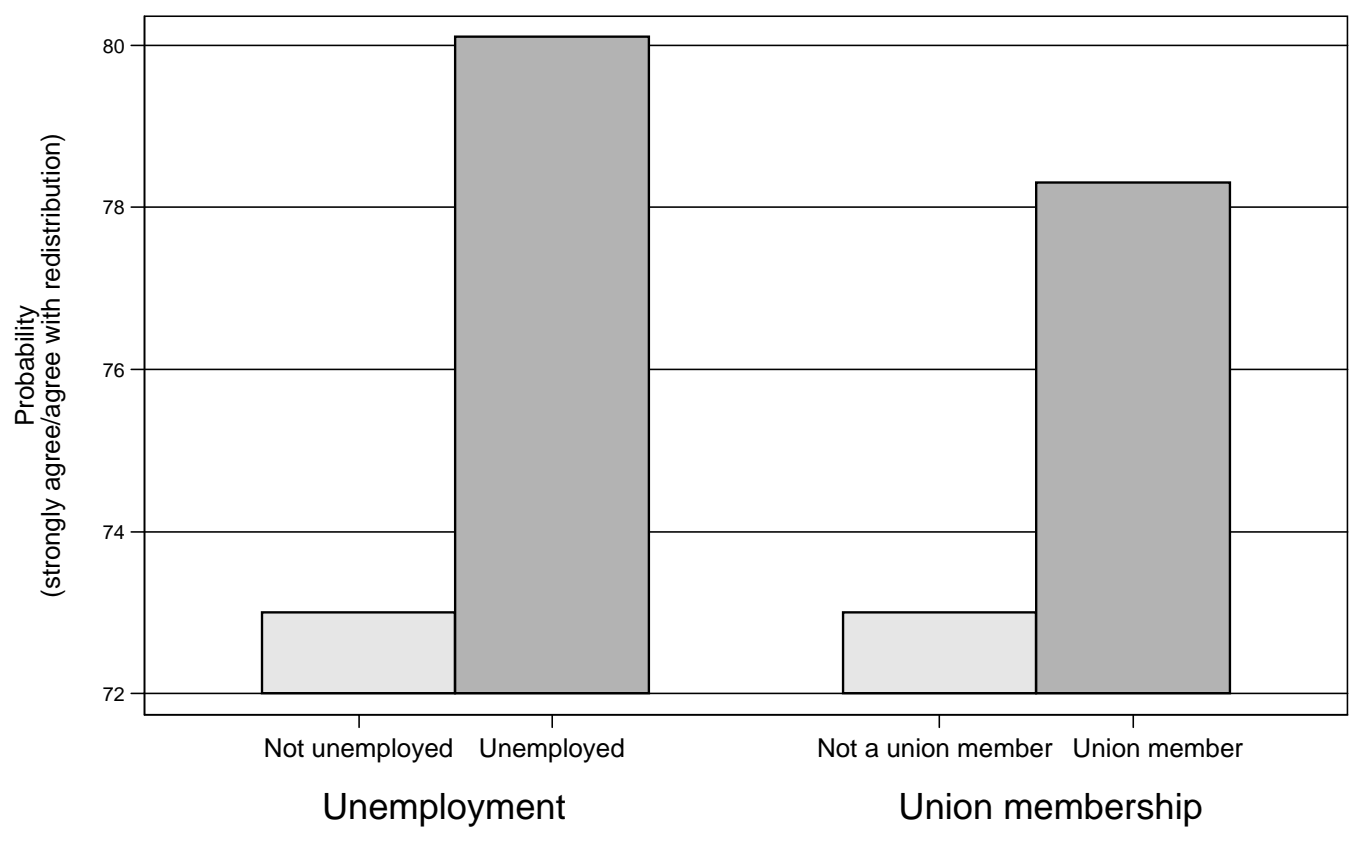

Note: Simulations with all variables set at their mean except dummies set at zero Simulations based on model 2 (table 1 )

Before turning to the independent variables of most interest in this paper, results for two other hypotheses that have been tested are presented.

\section{Meltzer \& Richard}

Recall the key result of Meltzer \& Richard's (1981) influential model: individuals with incomes above the national mean are not in favor of income redistribution while individuals below the mean income are. In order to test this proposition, the income variable had to be dropped from the estimation and replaced with a dummy variable indicating whether an individual's income was above or below the national mean income. ${ }^{45}$ It turns out that Meltzer \& Richard’s (1981) expectation has empirical support at the micro-level: "rich” individuals (i.e. individuals with abovemean income) are significantly less likely to support redistribution (table 1, model 3).

\footnotetext{
${ }^{45}$ Since the income variable and the dummy variable just mentioned are so closely related (their correlation coefficient is around 0.67 , which is extremely high for a large- $\mathrm{N}$ survey data-set), they cannot be left in the same model. Otherwise, the standard errors would suffer from multi-collinearity.
} 
The substantive effect, however, is relatively modest, at least compared to the effect of income. Graph 4 shows that the simulated probability of being in favor of redistribution of "rich" individuals is around 6.5\% lower than the probability of "poor" individuals (see graph 4, left side).

GRAPH 4: Substantive effect of (above or below mean) income and transfer dependence on preference for redistribution

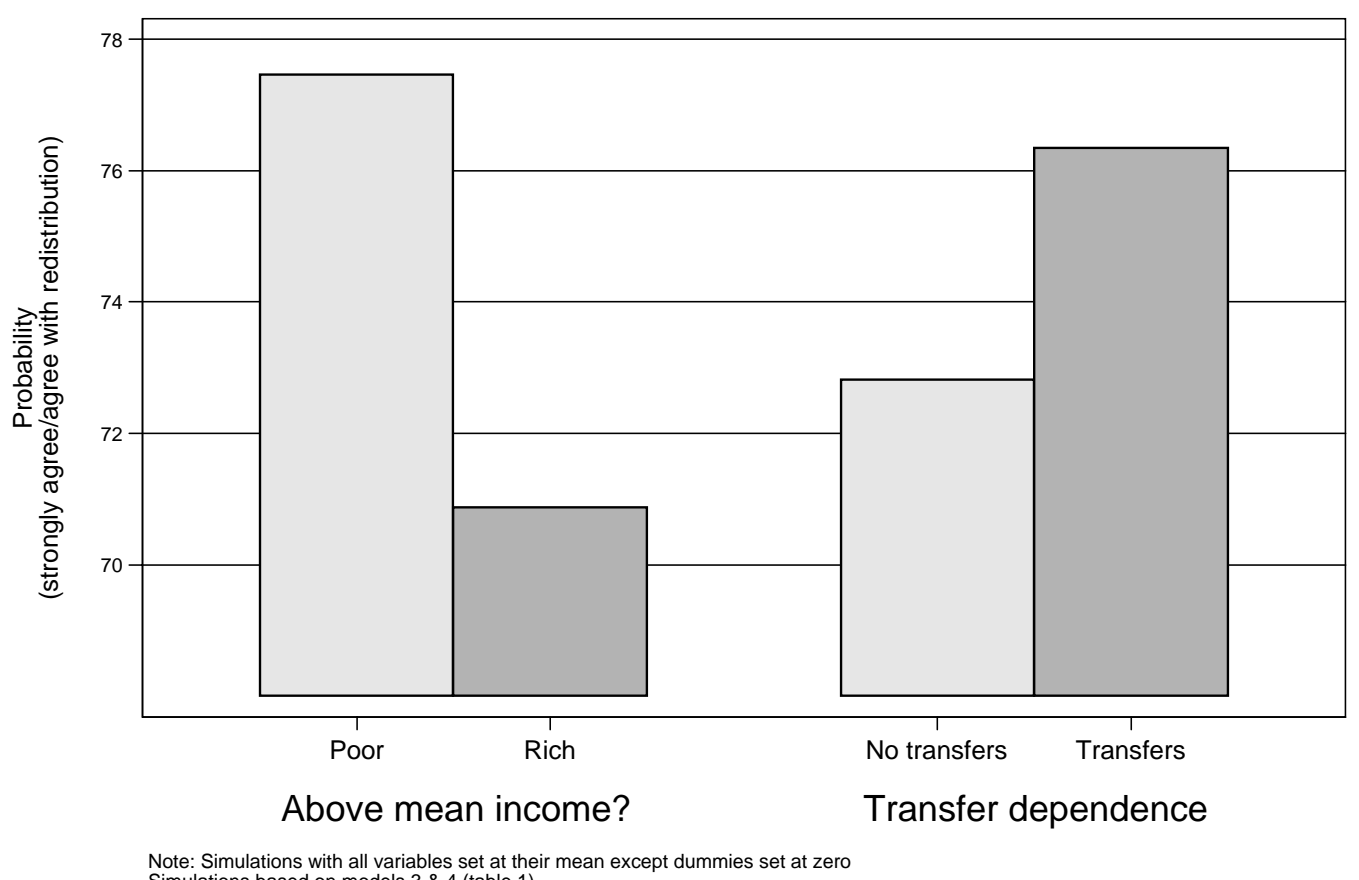
Note: Simulations with all variables set at their mean except dummies set at zero
Simulations based on models $3 \& 4$ (table 1 )

\section{Transfer dependence}

As was mentioned above, it has been argued that individuals who's main income source are government transfers can be expected to be in favor of redistribution. This transfer dependency hypothesis was tested in passing (table 1, model 4). Again, income has to be excluded from the estimation because income and transfer dependence highly correlate with each other (people who receive transfers tend to be poor). ${ }^{46}$ The statistical performance of the transfer variable is weak: although it is statistically significant in the estimation reported in table 1 , model 4 , the relationship is not very robust. Estimating the model with slightly different operationalizations of the

\footnotetext{
${ }^{46}$ The correlation coefficient is -0.38 .
} 
very same concept does not lead to a significant coefficient. In addition, the substantive effect of the reported coefficient is rather small. The two bars on the right side of graph 4 show that receiving transfers increases ones probability of being in favor of income redistribution by a mere $3.5 \%$.

For the purpose of this paper, the performance of the independent variables affecting or measuring the risk of unemployment is more interesting. The results are presented in the following paragraphs.

\subsubsection{Risk of unemployment}

\section{Structural change}

The structural change variable captures whether an individual's sector suffered from job losses or not. Table 2, model 5, reports the coefficient of this variable. Although the coefficient of the shown model is significant - at least at a generous significance level - this relationship cannot be assessed as robust. Slightly different operationalizations - e.g., structural change measured in a different year - only sometimes lead to significant coefficients. ${ }^{47}$ In addition, the substantive effect of the structural change variable is rather small (in the low 1-digits; not shown).

\footnotetext{
${ }^{47}$ This relationship was tested with a variety of indicators, including: a) different lags, i.e. sectoral employment changes between different time-points over the last 5 years or averages thereof; b) different functional forms. In particular, the variable was transformed according to Tversky \& Kahneman's (2000: 57, equation 5) empirically found utility functions, giving losses a greater weight than gains. In addition, the variable was recoded into a simple dummy distinguishing between individuals that worked in sectors that lost jobs vs. individuals that worked in sectors that did not lose jobs; c) different model specifications in order to avoid multi-collinearity; d) at different aggregate levels of the NACE classification (1- and 2-digit level, gendered or not); and e) different points of censoring. Please see the appendix for more details.
} 


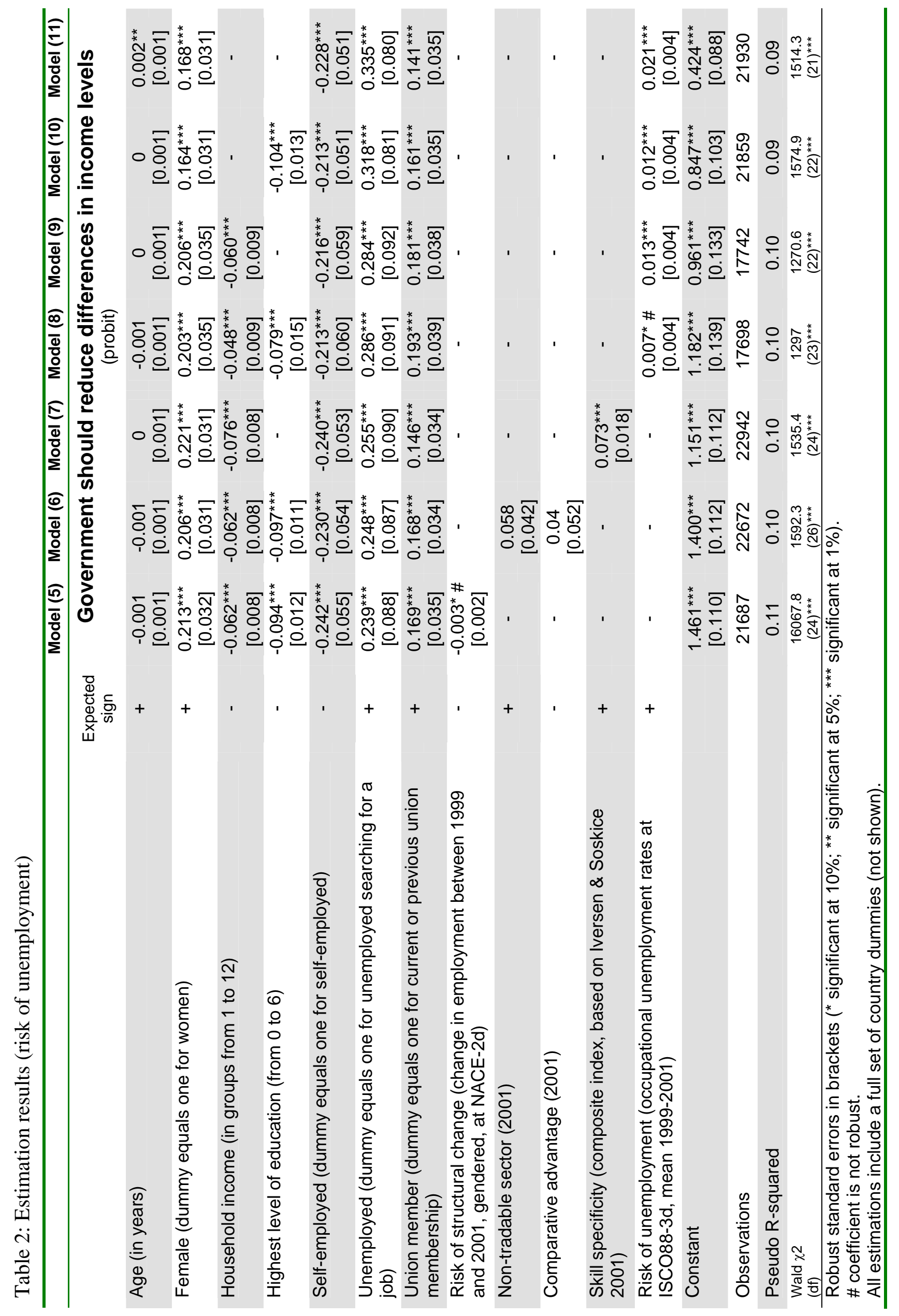


Therefore, one can conclude that structural change and the unemployment risks it brings about do not have a systematic impact on preferences over redistribution. This is somewhat surprising. There are a variety of potential explanations for this null-finding. a) The indicator may not be detailed enough. The most detailed available data are at the NACE 2-digit level. But the classification itself was developed at the 3-digit level. That means that changes at the most detailed (3-digit) level could cancel out on the aggregated 2-digit level. b) It may be that structural change is a factor that occurs slowly and has a delayed impact on individual preferences. The data-set does not allow for looking at long-term trends. c) Structural change may systematically covary with other factors shaping individual preferences over redistribution. In particular, structural change in OECD countries is usually skill biased so that the effect of structural change may be hidden behind the fact that unskilled individuals are over-proportionally in favor of redistribution anyway. d) Individuals may not care about their sector but about their occupation when it comes to preference formation. This seems very plausible because industrial classifications (such as NACE) lump workers, secretaries, managers etc. into one group because they work within the same sector. And e), of course, the suggested causal mechanism may simply be wrong.

\section{International competition}

There is no robust evidence that individuals working in non-tradable sectors are more in favor of redistribution than individuals employed in tradable sectors (table 2, model 6). In addition, the substantive effect of this variable is rather small (the probability of agreeing with redistribution increases by less than $5 \%$ if one simulates a change from employment in a tradable vs. a nontradable sector; not shown). Likewise, there is no evidence that a sector's position in the world market, i.e. its comparative advantage or disadvantage systematically influences preferences over redistribution of individuals working in that sector. ${ }^{48}$

This is the most important null-finding of this paper. Given the theoretical sophistication of these types of arguments and especially their prominence in the literature it is surprising not to find

\footnotetext{
${ }^{48}$ The following question was also employed as dependent variable: "Please say how much you agree or disagree with the following statements: All countries benefit if people can move to countries where their skills are most needed" (variable "ctbfsmv"). This is the best operationalization of 'preferences over trade' that one can get out of the ESS dataset. Although there are clearly a variety of problems with this dependent variable, one can argue that it taps the underlying concept (trade preferences) reasonably well. Even on this dependent variable, there is no empirical support for the conjecture that sectoral employment plays a systematic role in shaping individual preferences.
} 
any individual level empirical evidence supporting them. In order to understand this null-finding, one can make similar arguments as have been made above for explaining the absence of empirical support for the structural change hypothesis. If one recalls the sophistication of the arguments connecting international competitiveness and individual preferences brought forward in the literature, one can argue that the null-finding simply indicates that the suggested logic is wrong. It is a big leap of faith to assume that individuals without economics training understand the subtleties of trade-theories and their implications for job security. The micro-logic of these arguments seems to be too sophisticated to be actually at work. ${ }^{49}$

\section{Specific Skills}

Recall that it was hypothesized that individuals with specific skills are more in favor of income redistribution than people with general skills. Because of the way skill specificity is measured (see appendix), the control variable 'education' has to be excluded from the regression. In line with the findings in Iversen \& Soskice (2001), this paper finds that skill specificity is a statistically significant, substantively influential and robust determinant of individual level preferences over redistribution. Table 2 , model 7 , shows that individuals endowed with specific skills over-proportionally favor income redistribution. The impact of skill specificity on support for income redistribution is not only significant (and robustly so, see appendix ${ }^{50}$ ), but also substantial (see graph 5). Simulating a change from the lowest to the highest degree of skill specificity changes the probability of being in favor of income redistribution by roughly $18 \%$. The magnitude of this substantive effect is comparable to the effect of income or education.

\footnotetext{
${ }^{49}$ These findings do not imply that the suggested relationship between redistributional preferences and public vs. private employment have no empirical support. The data-set does not allow for testing this hypothesis.

${ }^{50}$ The results do not depend on which of the three skill specificity measures is employed. Also, the relationship holds if one excludes individuals not in the labor force. However, the inclusion of education as an independent variable makes the relationship less robust. But there are excellent reasons not to do so: the operationalization of skill specificity already controls for education.
} 
GRAPH 5: Substantive effect of skill specificity on preference for redistribution, by gender

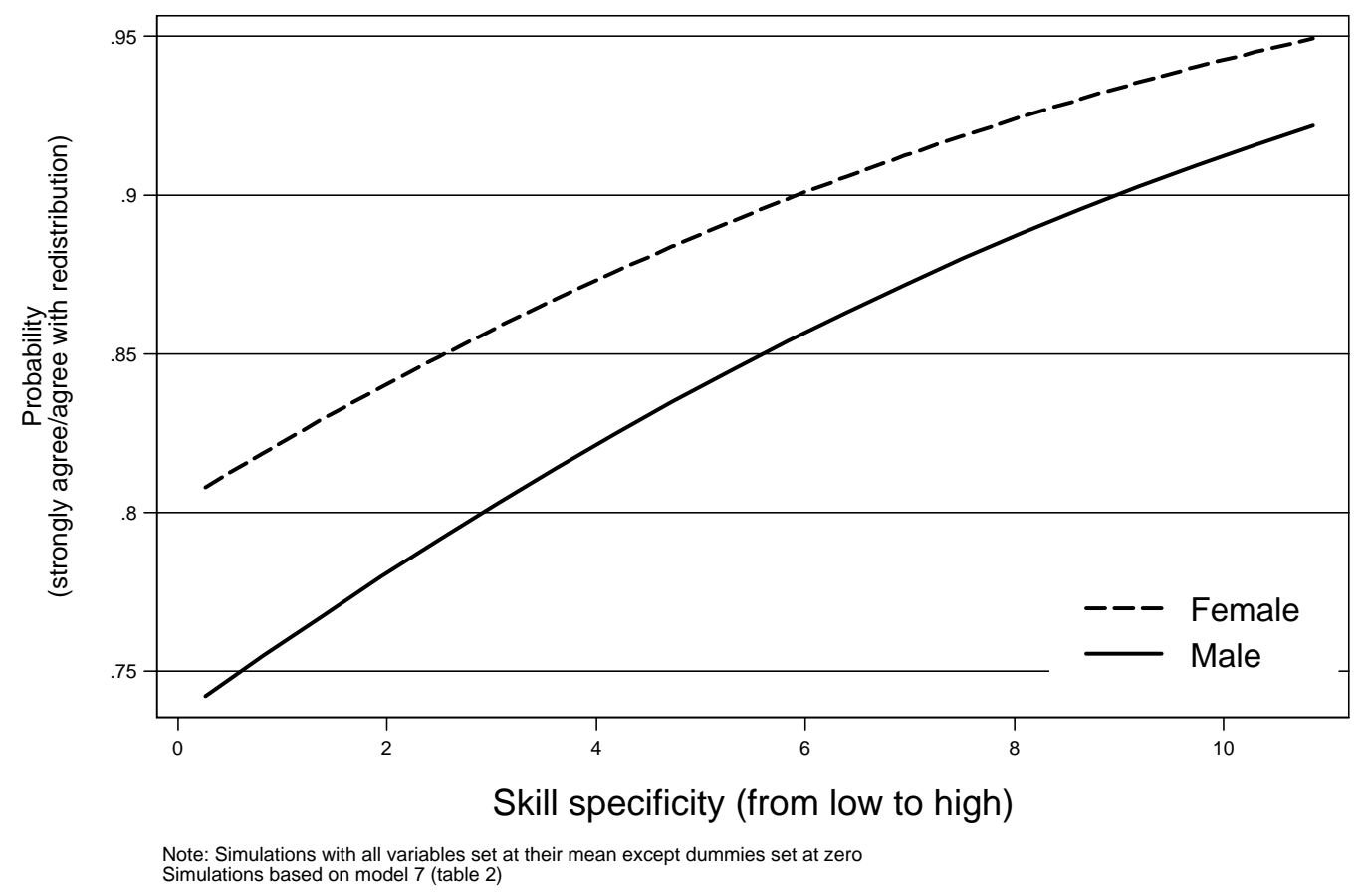

\section{Disadvantaged occupations}

The conjecture was that individuals exposed to a high risk of unemployment feel insecure and demand redistribution as insurance. This paper employs occupational unemployment rates in order to measure individual level risk. This operationalization fits the underlying concept quite well. There is good evidence that risk - measured by detailed occupational unemployment rates - indeed shapes preferences over redistribution. Table 2 (models 8 to 11) shows the estimation results with different control variables. The variable of interest - detailed occupational unemployment rates as an average from 1999 to 2001 - is significant and has the correct sign. ${ }^{51}$ The substantive effect of 'risk of unemployment' on preferences is large, especially once education and / or income are excluded from the equations. A simulated change from the lowest level of unemployment risk to the highest increases the probability of being in favor of redistribution by up to $18 \%$ (see graph 6 , solid line). ${ }^{52}$

\footnotetext{
${ }^{51}$ Once the multi-collinear variable education is excluded, this finding is very robust. The correlation coefficients between educational level and risk of unemployment as well as between income and risk of unemployment are -0.28 ${ }^{52}$ Simulations on estimations that include income and educational level as control variables shrink this probability to $7 \%$ (graph 7, dotted line). Because they are multi-collinear, there are excellent reasons to exclude them.
} 
GRAPH 6: Substantive effect of occupational unemployment rates on preference for redistribution

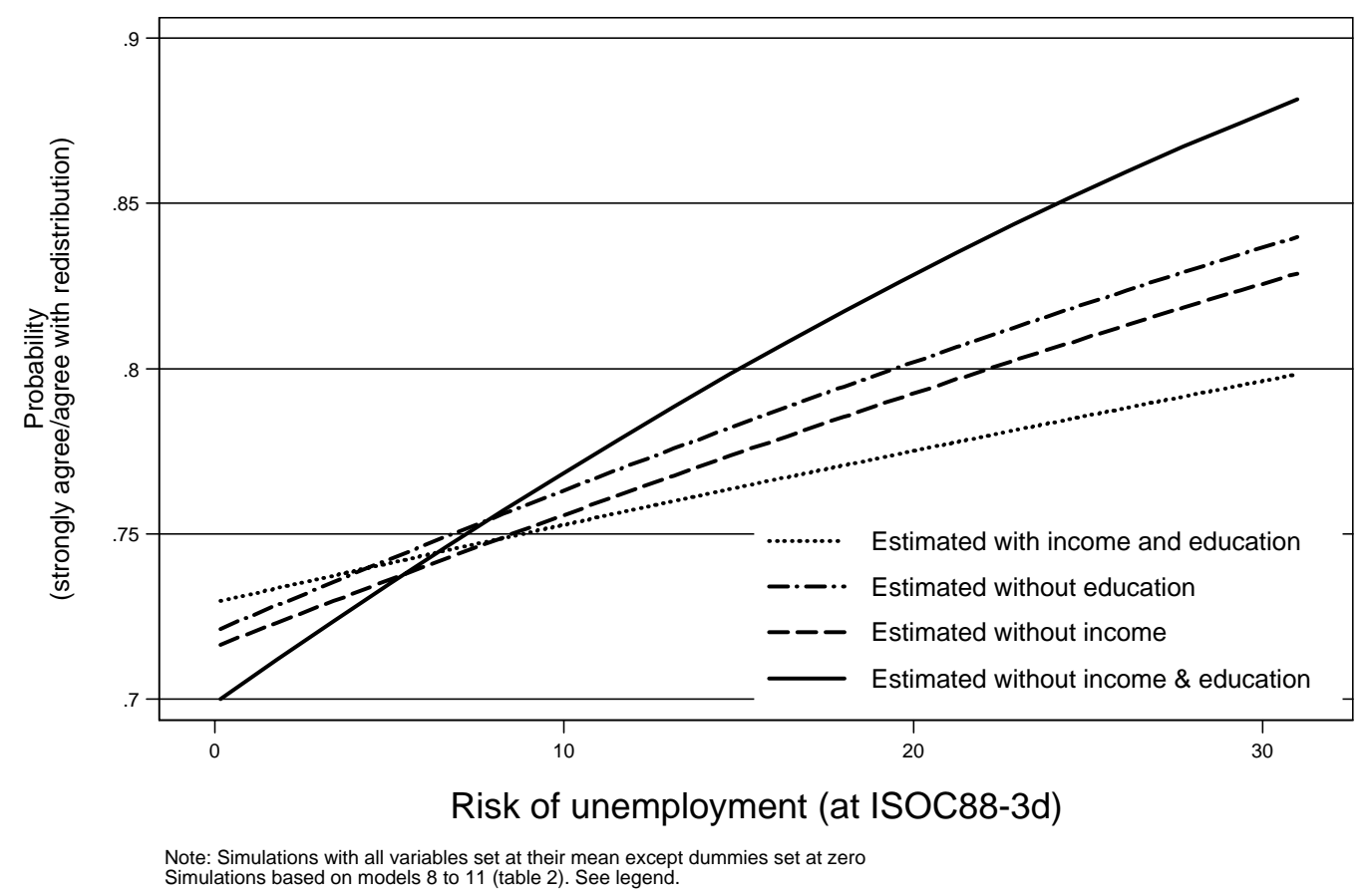

In sum, this paper shows that some of the factors measuring individual exposure to risk of job loss indeed shape individual preferences over redistribution in a meaningful way. More concretely, it can be shown that individuals with specific skills as well as individuals employed in disadvantaged occupations (measured with occupational unemployment rates) are overproportionally in favor of income redistribution. In contrast, structural change as well as exposure to international trade cannot be established as important determinants of individual support for redistribution. 


\section{Conclusion}

This paper suggests that there are two logics that influence preferences over redistribution. They are both important. First, individuals support redistribution because they are disadvantaged and hope to directly gain from income redistribution. This is the 'desire for equity' logic. Redistribution is a means of achieving equity. Income is the most important variable capturing this logic. Second, the 'redistribution-as-insurance' argument states that individuals are in favor of income redistribution because it insures them against the risks of income shocks, regardless of their incomelevel.

The paper explores the empirical utility of both logics, but focuses on the redistribution-asinsurance argument. By drawing on existing theories, the paper formulates hypotheses related to the redistribution-as-insurance argument. Structural change, international competitiveness, skill specificity and disadvantaged occupations are identified as potential determinants of individual preferences over redistribution. The paper brings forward a variety of novel measures to operationalize these concepts. Most importantly, it offers a measure of detailed occupational unemployment rates derived from labor force surveys. This measure distinguishes over 100 unemployment rates per country.

In order to evaluate the empirical utility of the redistribution-as-insurance logic, the paper tests the derived hypotheses, controlling for the redistribution as equity argument. Three criteria are considered in evaluating a variable's impact on preferences over income redistribution: a coefficient's statistical significance, its substantive effect, and its robustness. When using these criteria, the paper can establish that two factors measuring risk importantly influence redistributional preferences: skill specificity and occupational unemployment risk. Individuals with specific skills as well as individuals in occupations with high unemployment risks are overproportionally in favor of income redistribution. In contrast, the paper does not find empirical support for the conjecture that risks brought by an individual's sectoral employment determines preferences over redistribution. Neither structural change measured at the sectoral level nor a sector's position in the world-markets - measured by its comparative (dis)advantage - can be established as predictors of preferences over income redistribution. These findings suggest that the 
redistribution-as-insurance model has a certain degree of empirical utility. On the other hand, the null-finding on the international competitiveness variables raises questions about the sophisticated micro-logic suggested by the trade literature.

This paper focused on the redistribution-as-insurance logic of preference formation. Further work exploring this logic is needed. In particular, it seems fruitful to consider more factors that threaten an individual's income. Future work should not only control for the redistribution for equity argument - as in this paper - but explore it in detail. The sociological literature is a rich source for identifying factors that systematically determine life-chances (mainly class). Although this paper systematically controls for income as a crucial measure of the 'redistribution for equity' argument, a more systematic treatment of this logic would facilitate a comparison with the 'redistribution-as-insurance' argument.

Future work could also systematically consider contextual effects. In addition, exploring the determinants of redistributional preferences can serve as a building block for more fine-grained explorations of partisan preferences. Which socio-economic factors and preferences determine partisan preferences is an important question. As it stands, comparative attitudinal research is far from being able to offer conclusive findings. 


\section{Literature}

Andersen, Torben M. "International Integration, Risk and the Welfare State." Scandinavian Journal of Economics 104, no. 3 (2002): 343-64.

Arachi, Giampaolo, and Massimo D'Antoni. "Redistribution as Social Insurance and Capital Market Integration." In University of Siena Economics Working Paper No. 404, 2003.

Baldwin, Peter. "Die Sozialen Ursprünge des Wohlfahrtsstaates." Zeitschrift für Sozialreform 36, no. 11/12 (1990): 677-92.

The Politics of Social Solidarity: Class Bases of the European Welfare State, 1875-1975. Cambridge, MA: Cambridge University Press, 1990.

Barr, Nicholas. The Welfare State as Piggy Bank. Information, Risk, Uncertainty, and the Role of the State. Oxford: Oxford University Press, 2001.

Bates, Robert H., Philip Brock, and Jill Tiefenthaler. "Risk and Trade Regimes: Another Explanation." International Organization 45, no. 1 (1991): 1-18.

Becker, Gary. Human Capital: A Theoretical and Empirical Analysis with Special References to Education. Chicago: Chicago University Press, 1964.

Beramendi, Pablo, and Thomas R. Cusack. "Diverse Disparities: The Politics and Economics of Wage, Market and Disposable Income Inequalities." In Discussion Paper SP II 2004 - 08, Wissenschaftszentrum Berlin. Berlin, 2004.

Cameron, David R. "The Expansion of the Public Economy: A Comparative Analysis." American Political Science Review 72, no. 4 (1978): 1243-61.

Clark, Terry Nichols, and Seymour Martin Lipset. The Breakdown of Class Politics. Baltimore / London: Johns Hopkins University Press, 2001.

Clayton, Richard, and Jonas Pontusson. "Welfare-State Retrenchment Revisited: Entitlement Cuts, Public Sector Restructuring, and Inegalitarian Trends in Advanced Capitalist Societies." World Politics 51, no. 1 (1998): 64-98.

Converse, Philip E. "Information Flows and the Stability of Partisan Attitudes." Public Opinion Quarterly 26, no. 4 (1962): 578-97.

"The Nature of Belief Systems in Mass Publics." In Ideology and Discontent, edited by David. E. Apter, 206-61. New York: The Free Press, 1964.

Esping-Andersen, Gosta. Politics against Markets: The Social Democratic Road to Power. Princeton: Princeton University Press, 1985.

The Three Worlds of Welfare Capitalism. Princeton, NJ: Princeton University Press, 1990.

Estevez-Abe, Margarita, Torben Iversen, David Soskice, Peter Hall, and David Soskice. "Social Protection and the Formation of Skills: A Reinterpretation of the Welfare State." In Varieties of Capitalism, 145-83. Oxford: Oxford University Press, 2001.

Frieden, Jeffry. Debt, Development, and Democracy. Princeton, NJ: Princeton University Press, 1991.

Gelissen, John. Worlds of Welfare, Worlds of Consent? Leiden \& Boston: Brill, 2002.

Goldthorpe, John H., Anthony Giddens, and Gavin Mackenzie. "On the Service Class: Its Formation and Future." In Social Class and the Division of Labor, 162-85. Cambridge, MA: Cambridge University Press, 1982.

Hagle, Timothey M., and Glenn E. Mitchell II. "Goodness-of-Fit Measures for Probit and Logit." American Journal of Political Science 36, no. 3 (1992): 762-84.

Hegtvedt, Karen A. "When Is a Distribution Rule Just?" Rationality and Society 4, no. 3 (1992): 308-11. 
Herron, Michael C. "Postestimation Uncertainty in Limited Dependent Variable Models." Political Analysis 8, no. 1 (1999): 83-98.

Hiscox, Michael J. "Class versus Industry Cleavages: Inter-Industry Factor Mobility and the Politics of Trade." Industrial Organization 2001, 1-46.

Hiscox, Michael J. "Through a Glass and Darkly: Framing Effects and Individuals' Attitudes toward International Trade." Paper presented at Duke University 2003.

Inglehart, Ronald. "Post-Materialism in an Environment of Insecurity." American Political Science Review 75, no. 4 (1981): 880900 .

The Silent Revolution: Changing Values and Political Style. Princeton: Princeton University Press, 1977.

Iversen, Torben, and David Soskice. "An Asset Theory of Social Policy Preferences." American Political Science Review 95, no. 4 (2001): 875-93.

Jowell, Roger, and Central Co-ordinating Team. European Social Survey: Technical Report. London: Centre for Comparative Social Surveys, City University (producer) and Norwegian Social Science Data Services (distributors), 2002/2003.

Kahneman, Daniel, and Amos Tversky. "Prospect Theory: An Analysis of Decision under Risk By." Econometrica 47 (1979): $263-$ 91.

Katzenstein, Peter J. Small States in World Markets. Industrial Policy in Europe. Ithaca and London: Cornell University Press, 1985.

Kitschelt, Herbert. "Class-Structure and Social-Democratic Party Strategy." British Journal of Political Science 23 (1993): $299-337$.

The Transformation of European Social Democracy. Cambridge, MA: Cambridge University Press, 1994.

"Linkages between Citizens and Politicians in Democratic Polities." Comparative Political Studies 2000, 845-79.

Kitschelt, Herbert, and Philipp Rehm. "New Social Risk Constituencies and Political Parties." In Paper delivered at the conference on "The Politics of New Social Risks". Lugano, Switzerland, September 2003.

"Political Groups Alignments in Party Systems." In Paper prepared for the 14th Conference of the Council of European Studies. Chicago, March 11-13, 2004a.

"Social Class, Labor Unions, and Redistributive Politics. Does Labor Have the Potential and Manifest Capacity for Political Action?" In Paper prepared for delivery at the workshop "The End of Labor Politics?" Max Planck Institute for the Study of Societies, Cologne, June 17-18, 2004c.

"The Social Policy Preferences of New Social Risk Constituencies." In Paper prepared for the 14th Conference of the Council of European Studies. Chicago, March 11-13, $2004 \mathrm{~b}$.

Korpi, Walter. The Democratic Class Struggle. London: Routledge, 1983.

Kunovich, Robert M. "Social Structural Position and Prejudice: An Exploration of Cross-Sectional Differences in Regression Slopes." Social Science Research 2004, 20-44.

Lindert, Peter H. Growing Public. Social Spending and Economic Growth since the Eighteenth Century. Vol. 1: The Story. Cambridge, MA: Cambridge University Press, 2004.

Long, Scott J., and Jeremy Freese. Regression Models for Categorial Dependent Variables using Stata. College Station, TX: Stata, 2001 .

Manow, Philip. "Comparative Institutional Advantages of Welfare State Regimes and New Coalitions in Welfare State Reforms." In The New Politics of the Welfare State, edited by Paul Pierson, 146-64. Oxford: Oxford University Press, 2001.

"Sozialstaatliche Kompensation Außenwirtschaftlicher Öffnung?" In Nationaler Staat Und Internationale Wirtschaft. Anmerkungen Zum Thema Globalisierung, edited by Andreas Busch and Thomas Plümper, 197-222. Bade-Baden: Nomos, 1999. 
Mares, Isabela. The Politics of Social Risk. Business and Welfare State Development. Cambridge, MA: Cambridge University Press, 2003.

Mayda, Anna Maria, and Dani Rodrik. "Why Are Some People (and Countries) More Protectionist Than Others?" Unpublished manuscript 2002.

Meltzer, Allan H., and Scott F. Richard. "A Rational Theory of the Size of Government." Journal of Political Economy 1981, 914-27.

Moene, Karl O., and Michael Wallerstein. "Inequality, Social Insurance, and Redistribution." American Political Science Review 95, no. 4 (2001): 859-74.

Nieuwbeerta, Paul. "The Democratic Class Struggle in Postwar Societies. Traditional Class Voting in Twenty Countries, 1945-1990." Acta Sociologica 1995.

O'Rourke, Kevin H., and Richard Sinnott. "The Determinants of Individual Trade Policy Preferences: International Survey Evidence." Unpublished manuscript 2001.

Oesch, Daniel. "Analyzing Labour Market Stratification with a Modified Class Schema: A Study for Britain, Germany, Sweden and Switzerland." Unpublished manuscript 2003.

Page, Benjamin I., and Robert Y. Shapiro. The Rational Public: Fifty Years of Trends in Americans' Policy Preferences. Chicago: Chicago University Press, 1992.

Papadakis, Elim. "Public Opinion, Public Policy and the Welfare State." Political Studies XL (1992): 21-37.

Peillon, Michel. "A Qualitative Comparative Analysis of Welfare Legitimacy." Journal of European Social Policy 6, no. 3 (1996): $175-90$.

Pierson, Paul. Dismantling the Welfare State? Reagan, Thatcher, and the Politics of Retrenchment. Cambridge: Cambridge University Press, 1994.

"The New Politics of the Welfare State." World Politics 48, no. 2 (1996): 143-79.

Rawls, John. A Theory of Justice. Cambridge, MA: Cambridge University Press, 1971.

Rehm, Philipp. "Individual Preferences and the Potential for Political Cleavages." In Paper prepared for the Workshop "Analysis of Political Cleavages and Party Competition". Duke University, April 2-3, 2004a.

"On the Formation of Individual Preferences." Theme Paper. Duke University, 2004b.

Rieger, Elmar, and Stephan Leibfried. "Welfare State Limits to Globalization." Politics \& Society 26, no. 3 (1998): 363-91.

Riker, William. "Implications from the Disequilibrium of Majority Rule for the Study of Institutions." American Political Science Review 74 (1980): 432-46.

Rodrik, Dani. "Why Do More Open Economies Have Bigger Governments?" Journal of Political Economy 106, no. 5 (1998): $997-$ 1032.

Rodrik, Dani, Gene M. Grossman, and Kenneth Rogoff. "Political Economy of Trade Policy." In Handbook of International Economics, Vol. 3, 1457-94. Amsterdam: Elsevier, 1995.

Rogowski, Ronald. Commerce and Coalitions. How Trade Affects Domestic Political Alignments. Princeton, NJ: Princeton University Press, 1989.

"Political Cleavages and Changing Exposure to Trade." American Political Science Review 81, no. 4 (1987): 1121-37.

Scheve, Kenneth, and Matthew J. Slaughter. "Economic Insecurity and the Globalization of Production." NBER Working Papers 2002.

"Economic Insecurity and the Globalization of Production." American Journal of Political Science 2004, 622-74.

"What Determines Individual Trade-Policy Preferences?" Journal of International Economics 2001, 267-92. 
Shuey, Kim M., and Angela M. O'Rand. "New Risks for Workers: Pensions, Labor Markets, and Gender." Annual Review of Sociology 30, no. 1 (2004): 453-77.

Sinn, Hans-Werner. "Social Insurance, Incentives and Risk Taking." International Tax and Public Finance 3 (1996): 259-80.

"A Theory of the Welfare State." Scandinavian Journal of Economics 97, no. 4 (1995): 495-526.

Sniderman, Paul M., Richard A. Brody, and Philip E. Tetlock. Reasoning and Choice. Explorations in Political Psychology. Cambridge, MA: Cambridge University Press, 1991.

Svallfors, Stefan. "Class, Attitudes and the Welfare State: Sweden in Comparative Perspective." Social Policy \& Administration 38, no. 2 (2004): 119-38.

"Worlds of Welfare and Attitudes to Redistribution: A Comparison of Eight Western Nations." European Sociological Review 13 (1997): 283-304.

Taylor-Gooby, Peter, Hartley Dean, Moira Munro, and Gillian Parker. "Risk and the Welfare State." British Journal of Sociology 50, no. 2 (1999): 177-94.

Tversky, Amos, and Daniel Kahneman. "Advances in Prospect Theory Cumulative Representation of Uncertainty." In Choices, Values, and Frames, edited by Daniel Kahneman and Amos Tversky, 44-65. Cambridge, MA: Cambridge University Press, 2000 .

Varian, Hal R. "Redistributive Taxation as Social Insurance." Journal of Public Economics 14 (1980): 49-68.

Williamson, Oliver E. The Economic Institutions of Capitalism. Firms, Markets, Relational Contracting. New York: Free Press, 1985.

Zaller, John R. The Nature and Origins of Mass Opinion. Cambridge, MA: Cambridge University Press, 1992. 


\section{Appendix}

\section{Structural change}

From EU labor force data, the percentages of people employed within each NACE (Revision 1) 2-digit group were calculated, by country ${ }^{53}$ and gender. From the percentages and OECD data on (female, male ${ }^{54}$ ) civilian employment, the absolute number of people employed at NACE 2-digit were computed, for each year (maximum number of years: 1992 to 2003). Straightforwardly, in order to calculate percentage changes in employment for each sector $\left(j\right.$, at NACE, 2-digit ${ }^{55}$ ) within each country $(\mathrm{k})$, the following formula was used ( $\mathrm{t}$ is a time-index ${ }^{56}$ ):

$$
\text { percentage } \text { change }_{j k}=\frac{\text { employment }_{j k,(t)}-\text { employment }_{j k,(t-1)}}{\text { employment }_{j k,(t-1)}} * 100
$$

A negative number implies that a sector within one country lost jobs. A positive number implies that a sector did not lose job, and potentially gained jobs. ${ }^{57}$

In order to correct for implausible outliers, data were censored at $-17 \%$ and $+30 \%$ (these are the values approximately below the $5^{\text {th }}$ fifth and above the $95^{\text {th }}$ percentile, respectively). ${ }^{58}$ For robustness, two other specifications were employed, with very similar results: a) a dummy that equals one for individuals in industries that lost jobs and b) a non-linear transformation, as suggested by Tversky \& Kahneman (2000: 57, equation 3). This transformation captures empirically observed values of individual utility functions and be expressed as:

$v(x)=\left\{\begin{array}{c}x^{0.8} \text { if } x \geq 0 \\ -2.25 *(-x)^{0.8} \text { if } x<0\end{array}\right.$, where " $\mathrm{x}$ " is the percentage change in sectoral employment.

\section{International competition}

A sector's comparative advantage or disadvantage was computed as in Mayda \& Rodrik (2002: pp. 20), but with different data. A sector's revealed comparative (dis)advantage can be determined by looking at the sign of adjusted net exports in that sector (for various years or averages over several years). Simply put, a sector is said to have a comparative advantage if its exports (X) are greater than its imports (M), adjusted for a countries overall trade (im)balance.

The adjustment factor $\lambda$ is calculated as:

$$
\lambda=\frac{\sum_{j}\left(M_{j}-X_{j}\right)}{\sum_{j}\left(M_{j}\right)},
$$

\footnotetext{
${ }^{53}$ Belgium is missing.

${ }^{54}$ Changes were computed by gender as well as for totals. The regression results are the same.

${ }^{55}$ For robustness checks, these values were also computed at NACE, 1-digit. The estimation results are not influenced by the variable's detail.

${ }^{56}$ Different time-differences do not lead to different findings.

${ }^{57}$ Without further information (e.g., wage data), it is not clear whether a positive number simply implies whether the sector actually grew or whether the existing jobs were taken over by other workers (usually in order to replace older workers).

${ }^{58}$ Other censoring points do not lead to different findings.
} 
where the subscript " $\mathrm{j}$ " stands for the countries' sectors. The adjustment factor serves the purpose of correcting for the existence of overall trade imbalances. The indicator $\lambda$ is positive (negative) for countries that have a trade deficit (surplus). "In particular, $\lambda$ tells us by what fraction imports in each sector would have to be reduced in order to balance the trade account" (Mayda \& Rodrik 2002). A sector, then, has a comparative advantage (disadvantage) if the following expression is smaller (greater) than zero:

$$
\text { Comparative (dis)advantage: sign }\left\{(1-\lambda) M_{j k}-X_{j k}\right\} \text {, }
$$

where the subscript " $\mathrm{j}$ " stands for sectors and " $\mathrm{k}$ " for the different countries.

The ESS data-set contains a variable which assigns each respondent a two-digit NACE (Revision 1) code. Since there are no trade-data according to the NACE-classification, this paper exploits the relationship between NACE Revision 1 and ISIC Revision 3 (they are essentially the same). ${ }^{59}$ The latter is related to the "Harmonized Commodity Description and Coding System 1996 (HS 1996)", which is used in OECD's "International Trade by Commodity Statistics (ITCS)." This database is "a unique and reliable source of yearly statistical data in imports and exports in OECD countries" (OECD about OECD data). It provides very detailed data on values and quantities imand exported, at the 6-digit HS 1996 level. ${ }^{60}$ The 6-digit (HS 1996) codes were mapped onto the 2digit codes in the ESS data-set (NACE, Revision 1). The non-tradable category is a residual category: if as sector neither has a comparative advantage nor a disadvantage, it does not trade. ${ }^{61}$ Usually, the following sectors are coded as non-tradable: $37,41-73,75-91,95,99{ }^{62}$

\section{Specific Skills}

The operationalization of skill specificity follows essentially Iversen \& Soskice (2001). There is one difference, however: instead of calculating the "LFS-shares" (see below) with survey data, EU labor force data were used instead.

There are three skill specificity measures: s1, s2, and s_comp. The details of their operationalization are:

$$
s 1=\frac{\frac{1}{2}(\text { shares } 1 d+\text { shares } 2 d)}{\text { skill level }} ; \quad s 2=\frac{\frac{1}{2}(\text { shares } 1 d+\text { shares } 2 d)}{\text { educational level }} ; \quad s_{-} \text {comp }=\frac{s 1+s 2}{2}
$$

\footnotetext{
${ }^{59}$ All trade concordance tables are taken from Eurostat's Classification Server, called RAMON ( http://europa.eu.int/comm/eurostat/ramon/cgi/SimWWWFrame.SimBottomFrame?p_nID=\&p_1Id=1\&p_pId=\&p_langn $\mathrm{om}=\& \mathrm{p}$ frameType $=1 \& \mathrm{p}$ asso $=\& p \mathrm{emp}=\& \mathrm{p}$ language $=\mathrm{EN})$.

${ }^{60}$ Code 1509 , e.g., contains "Olive oil and its fractions, whether or not refined, but not chemically modified" - and this is only the 4-digit level!

${ }^{61}$ There is no case in which the calculation of a sector's comparative (dis)advantage returns a zero.

${ }^{62}$ Recycling (37), Collection, purification, and distribution of water (41), Construction (45), Wholesale and retail trade; repair of motor vehicles, motorcycles and personal and household goods (50-52), Hotels and restaurants (55), Transport, storage and communication (60-64), Financial intermediation (65-67), Real estate, renting and business activities (7073, not 74 (other business activities)), Public administration and defense; compulsory social security (75), Education (80), Health and social work (85), Sewage and refuse disposal, sanitation and similar activities (90), Activities of membership organizations n.e.c. (91), Private households with employed persons (95), Extra-territorial organizations and bodies (99).

Some countries, however, have a few more non-tradable sectors because they do not trade every good.
} 
where:

sharesld

$=\frac{\text { ISCO classification share at ISCO88_1d" }}{\text { "LFS share at ISCO88_1d" }}=$

$=\frac{(\text { "number of 4digit units within 1digit major group")/("total number of 4digit units") }}{\text { ("number of people in a 1digit ISCO_group")/("number of people in the labor force") }}$

shares $2 d$

$=\frac{\text { ISCO classification share at ISCO88_2d" }}{\text { "LFS share at ISCO88_2d" }}=$

- ("number of 4digit units within 2digit major group")/("total number of 4digit units")

$=\frac{(" n u m b e r}{\text { of people in a 2digit ISCO_group")/("number of people in the labor force") }}$

and "skill level" is the ILO coding for each ISCO88, 1-digit skill level ${ }^{63}$ and "educational level" is the education variable described below. ${ }^{64}$

Finally, the s1, s2, and s_comp measures are divided by their standard deviations.

\section{Disadvantaged occupations}

In order to compute detailed occupational unemployment rates, the paper exploits EU labor force surveys. First, it was calculated how many percent of all classified people were employed and unemployed, at ISCO88, 3-digit, by country. ${ }^{65}$ These percentages were, second, used for computing the absolute number of people employed and unemployed, taking standardized OECD civilian (un)employment data. Then, the following formula was used to derive the unemployment rate at ISCO88, 3-digit (j) within each country (k):

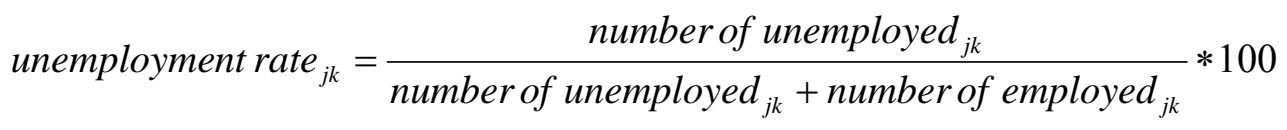

This was done for several years (maximum number of years: 1992-2003). For robustness tests, unemployment rates at ISCO88, 2-digit and 1-digit were also computed and employed in the estimations. The latter could also be computed by gender. The results for all variables are very similar.

\footnotetext{
${ }^{63}$ ISCO88-1d category "1" does not have a skill level assignment from the ILO. The highest skill level (4) was assigned to it.

${ }^{64}$ In order to avoid divisions by zero, the scale of the educational variable was shifted up by one (1).

${ }^{65}$ France and the Netherlands are missing.
} 


\section{Other variables}

All other variables were taken from inside the ESS data-set. Their operationalization is as follows:

- Preferences for redistribution (five-categories for ordered probit estimations. From low (1 = disagreement with income redistribution) to high (5=agreement with income redistribution)). Taken from "gincdif", scale reversed.

- Preferences for redistribution (dummy variable equals one (1) if individual agrees or strongly agrees with income redistribution, zero (0) otherwise, for probit estimations). Taken from "gincdif”, recoded.

- Age (in years). Taken from “yrbrn” (age=(2003-yrbrn)+1). People younger than 15 and older than 99 were coded as missing.

- Gender (dummy variable equals one (1) if female, zero (0) otherwise). Taken from "gndr."

- Income (household income in 12 groups, from lowest to highest). Taken from "hinctnt".

- Income above mean income (dummy variable equals one (1) if income above country mean income, zero (0) otherwise). Computed from 'income' (see above).

- Transfer dependence (dummy variable equals one (1) if main source of household income is transfer payments, zero (0) otherwise). Taken from "hincsrc" (transfer dependent if main source of income equals 3 ("pensions"), 4 (“unemployment / redundancy benefit”), or 5 (“any other social benefits or grants")). For robustness tests, each of these three categories was also coded into separate dummy variables.

- Education (highest level, in 7 categories from low (0) to high (6)). Taken from "edulvl."

- Self-employment (dummy variable equals one (1) if self-employed, zero (0) otherwise). Taken from “empl” (self-employed if empl equals 2 (“self-employed”)).

- Unemployment, searching for job (dummy variable equals one (1) if unemployed and searching for job, zero (0) otherwise). Taken from "uempla” (unemployed, searching for job if uempla equals 1 (“Doing last 7 days: unemployed, actively looking for job”)). 

Bücher des Forschungsschwerpunkts Markt und politische Ökonomie

Books of the Research Area Markets and Political Economy

Pablo Beramendi

Decentralization and Income Inequality

2003, Madrid: Juan March Institute

Thomas Cusack

A National Challenge at the Local Level: Citizens, Elites and Institutions in Reunified Germany

2003, Ashgate

Sebastian Kessing

Essays on Employment Protection

2003, Freie Universität Berlin,

http://www.diss.fu-berlin.de/2003/202

Daniel Krähmer

On Learning and Information in Markets and

Organizations

2003, Shaker Verlag

Bob Hancké

Large Firms and Institutional Change. Industrial

Renewal and Economic Restructuring in France

2002, Oxford University Press

Andreas Stephan

Essays on the Contribution of Public Infrastruc-

ture to Private: Production and its Political

Economy

2002, dissertation.de

Peter A. Hall, David Soskice (Eds.)

Varieties of Capitalism

2001, Oxford University Press

Hans Mewis

Essays on Herd Behavior and Strategic Delegation

2001, Shaker Verlag

Andreas Moerke

Organisationslernen über Netzwerke - Die

personellen Verflechtungen von Führungsgremien

japanischer Aktiengesellschaften

2001, Deutscher Universitäts-Verlag

Silke Neubauer

Multimarket Contact and Organizational Design

2001, Deutscher Universitäts-Verlag

Lars-Hendrik Röller, Christian Wey (Eds.)

Die Soziale Marktwirtschaft in der neuen

Weltwirtschaft, WZB Jahrbuch 2001

2001, edition sigma

Michael Tröge

Competition in Credit Markets: A Theoretic

Analysis

2001, Deutscher Universitäts-Verlag

Torben Iversen, Jonas Pontusson, David Soskice

(Eds.)

Unions, Employers, and Central Banks

2000, Cambridge University Press
Tobias Miarka

Financial Intermediation and Deregulation:

A Critical Analysis of Japanese Bank-Firm-

Relationships

2000, Physica-Verlag

Rita Zobel

Beschäftigungsveränderungen und

organisationales Lernen in japanischen

Industriengesellschaften

2000, Humboldt-Universität zu Berlin

http://dochost.rz.hu-berlin.de/dissertationen/zobel-rita2000-06-19

Jos Jansen

Essays on Incentives in Regulation and Innovation 2000, Tilburg University

Ralph Siebert

Innovation, Research Joint Ventures, and

Multiproduct Competition

2000, Humboldt-Universität zu Berlin

http://dochost.rz.hu-berlin.de/dissertationen/siebert-

ralph-2000-03-23/

Damien J. Neven, Lars-Hendrik Röller (Eds.)

The Political Economy of Industrial Policy in

Europe and the Member States

2000, edition sigma

Jianping Yang

Bankbeziehungen deutscher Unternehmen:

Investitionsverhalten und Risikoanalyse

2000, Deutscher Universitäts-Verlag

Christoph Schenk

Cooperation between Competitors -

Subcontracting and the Influence of Information,

Production and Capacity on Market Structure and

Competition

1999, Humboldt-Universität zu Berlin

http://dochost.rz.hu-berlin.de/dissertationen/schenkchristoph-1999-11-16

Horst Albach, Ulrike Görtzen, Rita Zobel (Eds.)

Information Processing as a Competitive

Advantage of Japanese Firms

1999, edition sigma

Dieter Köster

Wettbewerb in Netzproduktmärkten

1999, Deutscher Universitäts-Verlag

Christian Wey

Marktorganisation durch Standardisierung: Ein

Beitrag zur Neuen Institutionenökonomik des

Marktes

1999, edition sigma 

Annette Boom

Kai A. Konrad Wolfram F. Richter

Stergios Skaperdas

Johan Lagerlöf

Roman Inderst Christian Wey

Sebastian Kessing Robert Nuscheler Lars Frisell

Paul Heidhues Nicolas Melissas

Pablo Beramendi

Daniel Krähmer

Ralph Siebert

Vivek Ghosal

Vivek Ghosal

Andreas Blume

Paul Heidhues

Sebastian Kessing

Tomaso Duso Astrid Jung

Thomas R. Cusack Pablo Beramendi

Kjell Erik Lommerud Frode Meland Odd Rune Straume Joseph Clougherty
Investments in Electricity Generating Capacity under Different Market Structures and with Endogenously Fixed Demand

Zur Berücksichtigung von Kindern bei umlagefinanzierter Alterssicherung

Restraining the Genuine Homo Economicus: Why the Economy cannot be divorced from its Governance

Insisting on a Non-Negative Price: Oligopoly, Uncertainty, Welfare, and Multiple Equilibria

Buyer Power and Supplier Incentives

Monopoly Pricing with Negative Network Effects: The Case of Vaccines

The Breakdown of Authority

Equilibria in a Dynamic Global Game: The Role of Cohort Effects

Political Institutions and Income Inequality: The Case of Decentralization

Learning and Self-Confidence in Contests

The Introduction of New Product Qualities by Incumbent Firms: Market Proliferation versus Cannibalization

Impact of Uncertainty and Sunk Costs on Firm Survival and Industry Dynamics

Endemic Volatility of Firms and Establishments: Are Real Options Effects Important?

Private Monitoring in Auctions

Delay in Joint Projects

Product Market Competition and Lobbying Coordination in the U.S. Mobile

Telecommunications Industry

Taxing Work: Some Political and Economic Aspects of Labor Income Taxation

Globalisation and Union Opposition to Technological Change

Industry Trade-Balance and Domestic Merger Policy: Some Empirical Evidence from the U.S.
SP || $2003-14$

SP || $2003-01$

SP || $2003-02$

SP || $2003-03$

SP || $2003-04$

SP II $2003-05$

SP || $2003-06$

SP || 2003- 07

SP || 2003-08

SP || $2003-09$

SP || $2003-10$

SP I| $2003-11$

SP || $2003-12$

SP || $2003-13$

SP || $2003-15$

SP || $2003-16$

SP || $2003-17$

SP II $2003-18$

SP || $2003-19$ 
Dan Anderberg Fredrik Andersson

Eugenio J. Miravete Lars-Hendrik Röller

Talat Mahmood Klaus Schömann

Talat Mahmood Klaus Schömann

Suchan Chae Paul Heidhues

Sigurt Vitols

Michal Grajek

Kai A. Konrad

Helmut Bester

Kai A. Konrad

Kai A. Konrad

Kai A. Konrad

Steffen Huck Kai A. Konrad
Stratification, Social Networks in the Labour Market, and Intergenerational Mobility

Estimating Markups under Nonlinear Pricing Competition

On the Migration Decision of IT-Graduates:

A Two-Level Nested Logit Model

Assessing the Migration Decision of Indian IT-Graduates: An Empirical Analysis

Buyers Alliances for Bargaining Power

Negotiated Shareholder Value: The German Version of an Anglo-American Practice

Estimating Network Effects and Compatibility in Mobile Telecommunications

Bidding in Hierarchies

Easy Targets and the Timing of Conflict

Opinion Leaders, Influence Activities and Leadership Rents

Mobilität in mehrstufigen Ausbildungsturnieren

Moral Cost, Commitment and Committee Size
SP || $2003-20$

SP || $2003-21$

SP || 2003- 22

SP || $2003-23$

SP || $2003-24$

SP || $2003-25$

SP || 2003- 26

SP || 2003- 27

SP || $2003-28$

SP || $2003-29$

SP || $2003-30$

SP || $2003-31$ 
Jos Jansen

Johan Lagerlöf

Lars Frisell

Sigurt Vitols

Lutz Engelhardt

Antonio Guarino

Steffen Huck

Thomas D. Jeitschko

Thomas Plümper

Vera E. Troeger

Ulrich Kaisera

Pablo Beramendi Thomas R. Cusack Joseph Clougherty

Joseph Clougherty

Anming Zhang

Roel C.A. Oomen

Robert J. Franzese,Jr. Jude C. Hays

Albert Banal-Estañol Inés Macho-Stadler Jo Seldeslachts

Oz Shy Rune Stenbacka Jonathan Beck

Michal Grajek

Paul Heidhues Botond Kőszegi
Partial Information Sharing in Cournot Oligopoly

Lobbying, Information Transmission, and Unequal

Representation

Changes in Germany's Bank Based Financial System: A Varieties of Capitalism Perspective

Entrepreneurial Business Models in the German Software Industry: Companies, Venture Capital, and Stock Market Based Growth Strategies of the ,Neuer Markt'

Can Fear Cause Economic Collapse?

Insights from an Experimental Study

External Effects of Currency Unions

An Estimated Model of the German Magazine Market

Diverse Disparities: The Politics and Economics of Wage, Market and Disposable Income Inequalities

Antitrust Holdup Source, Cross-National Institutional Variation, and Corporate Political Strategy Implications for Domestic Mergers in a Global Context

Export Orientation and Domestic Merger Policy: Theory and Some Empirical Evidence

Modelling Realized Variance when Returns are Serially Correlated

Modeling International Diffusion: Inferential Benefits and Methodological Challenges, with an Application to International Tax Competition

Mergers, Investment Decisions and Internal Organisation

Price Competition, Business Hours, and Shopping Time Flexibility

Fixed, focal, fair? Book Prices Under Optional resale Price Maintenance

Diffusion of ISO 9000 Standards and International Trade

The Impact of Consumer Loss Aversion on Pricing

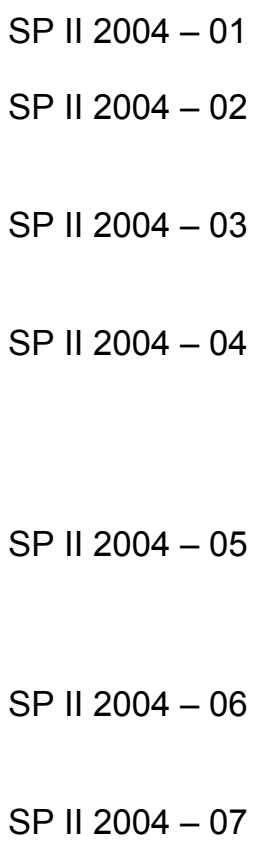


Lutz Engelhardt Geschäftsmodelle und nationale Institutionen: Ein Vergleich britischer und deutscher Neuemissionen aus der IT-Service- und Softwareindustrie 1996 2002

Philipp Rehm
SP || $2005-01$

SP || $2005-02$ of Preferences for Income Redistribution 
Bei Ihren Bestellungen von WZB-Papers schicken

Sie bitte unbedingt einen an Sie adressierten Auf-

kleber mit sowie je paper eine Briefmarke im Wert

von 0,51 Euro oder einen "Coupon Reponse Inter-

national " (für Besteller aus dem Ausland)
Please send a self addressed label and postage stamps in the amount of 0.51 Euro or a "CouponReponse International" (if you are ordering from outside Germany) for each WZB-paper requested

Absender I Return Address:

Wissenschaftszentrum Berlin

für Sozialforschung

Presse- und informationsreferat

Reichpietschufer 50

D-10785 Berlin-Tiergarten

Hiermit bestelle ich folgende(s)

Discussion paper(s):

Please send me the following Discussion paper(s):

Bestell-Nr. I Order no.

Autor/in, Kurztitel /Author(s) / Title(s) in brief 